\title{
Residential House Prices, Commercial Real Estate Lending and Bank Failures
}

\author{
Gerald A. Hanweck Sr ${ }^{1}$, Anthony B. Sanders ${ }^{1}$ and Gary S. Fissel ${ }^{2}$ \\ ${ }^{I}$ Professor of Finance, School of Business, George Mason University, Virginia, USA \\ ${ }^{2}$ Independent Researcher, USA
}

*Correspondence: Gerald A. Hanweck Sr, ghanweck@gmu.edu

\begin{abstract}
We investigate factors leading to bank failures during and after the Great Recession and banking crisis (2008-2015). The FHFA residential real estate house price index (HPI) for each of the 9 Census regions is used to interact with bank mortgage loans and bank financial statement variables. We find that these variables isolate different regional effects on the likelihood of a bank failing. Since we use changes from region to region, we find that regional location and HPI changes have an effect on banks' commercial lending activity. Other more traditional and associated factors, like construction and land development lending or multifamily real estate lending, similarly explain bank failures during the main period of the banking crisis. By using this approach we better isolate the relationship between residential house prices and builders' and land developers' desire to borrow and the willingness of banks to concentrate portfolio lending in commercial real estate.
\end{abstract}

KEYWORDS: Bank failures, Construction and land development Lending, Residential HPI, Residential mortgage Lending, Simulation modeling

JEL Classification Codes: G201, G31, G32, R32, R12, C690

\section{ARTICLE INFORMATION}

Author(s): Gerald A. Hanweck Sr, Anthony B. Sanders and Gary S. Fissel

Received: 29 Jul, 2021; Accepted: 16 Aug, 2021; Published: 30 Sep, 2021 e-ISSN: 2347-4696;

Paper Id: BMN-IJBMR-2021-59;

Citation: doi.org/10.37391/IJBMR.090314

Webpage-link:

https://ijbmr.forexjournal.co.in/archive/volume-9/ijbmr-090314.html

\section{INTRODUCTION}

Toxic residential mortgages, loans to borrowers with relatively poor credit, was thought to have led to banking troubles in 2008-2010. The FDIC reported that it closed more than 300 smaller depository institutions during the 2008-2010 time period. We find that real-estate loans played an important role in determining which banks survived and which banks failed. Real estate construction and development loans, commercial mortgages, and multi-family mortgages are consistently associated with a higher likelihood of bank failure. However, residential single-family mortgages are either neutral or associated with a lower likelihood of bank failure.

This study uses financial data from the individual banks' Reports of Income and Condition (Call Reports) with additional explanatory variables reflecting residential house lending interacted with HPI relative changes by census regions (regional HPI change-house loan interactions). We include, along with financial characteristics of banks, these interaction terms that identify bank residential mortgage lending activity coupled with regional house price index annual changes to capture the effects of the residential house price movements on banks' likelihoods of failure. Identifying the effects on bank failure of these more dynamic regional house price change interaction variables affect bank residential loan activity.
Interacted with HPI rates of change is expected to help isolate the effects of residential mortgage lending when house prices change. In this way, the impacts on banks' financial conditions are directly focused on their residential mortgage lending activities because these loans are on bank balance sheets from the time they were either originated or purchased.

House prices not only affect residential mortgage lending but other real estate lending by banks, especially construction and land development lending. Falling or stagnant house prices impact the valuation of real estate as indicators of value. Commercial real estate projects, such as construction and land development, will lose value as the construction project may experience a decline in value and the demand for land to develop declines as residential prices fall. The relationship between residential house prices, as indicated by the HPI, and other real estate values is reasonably direct and predictable.

Our modeling approach is similar to the traditional bank failure approach as used recently by Cole and White [1]. In their model, as in ours, selected bank-reported financial variables are used, but with the addition of the regional HPI change-house loan interactions to show that they are important explanatory factors in a bank failure, especially during the Great Recession period. Given the unique movements in these house price changes over this period, our model was not able to yield precise out-of-sample predictions, but the in-sample predictions and log-likelihood tests of goodness of fit do show greater predictive accuracy by including regional HPI changehouse loan interactions in the model. Other studies also use a similar traditional approach by using mostly bank-reported financial variables to estimate bank failure/survival. Sun, et al. [2] uses bank-reported data to find a general significance between bank failures and house price changes over crisis periods but do not identify locations for these effects, and Berger and Bouwman [3] focus on the effects of bank capital 
modifications during financial crises.

The relatively large effect of residential house price declines can be seen by the banks' balance sheet holdings of residential real estate loans in Figure 1. ${ }^{1}$ It shows the average relative holdings of these loans scaled by total assets from March 1999 through December 2016 for five separate asset size groups of banks - greater than $\$ 250$ billion, $\$ 10$ to $\$ 250$ billion, $\$ 1$ to $\$ 10$ billion, $\$ 100$ million to $\$ 1$ billion, and less than $\$ 100$ million. The largest two groups of banks quickly increased their residential real estate holdings before the crisis and held at least $25 \%$ of their assets in these loans until the end of 2008. We also note that the $\$ 100$ million to $\$ 1$ billion group of banks held at least $20 \%$ of their assets in residential loans through mid-2011. Figure 2 shows that for all banks, their non-revenue generating (noncurrent plus charge-off) loan performance in this loan category averaged $3 \%$ of these loans in 2009Q42010Q4 period. Its peak value over this period is 2 times larger than its 2000-2016 average value.

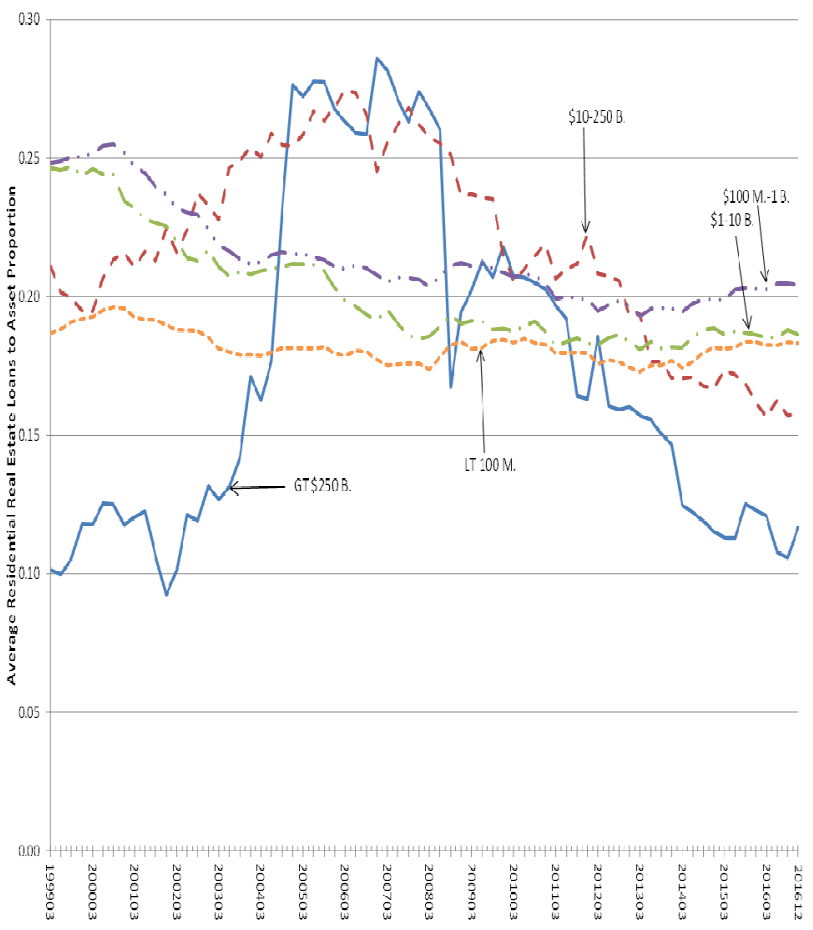

Figure 1: Average Residential Real Estate Loan to Asset Proportion by Asset-Size Group (Source: FDIC, Bank Reports of Income and Condition, various years).

1 Individual bank reported financial data comes from Reports of Income and Condition (Call Reports).

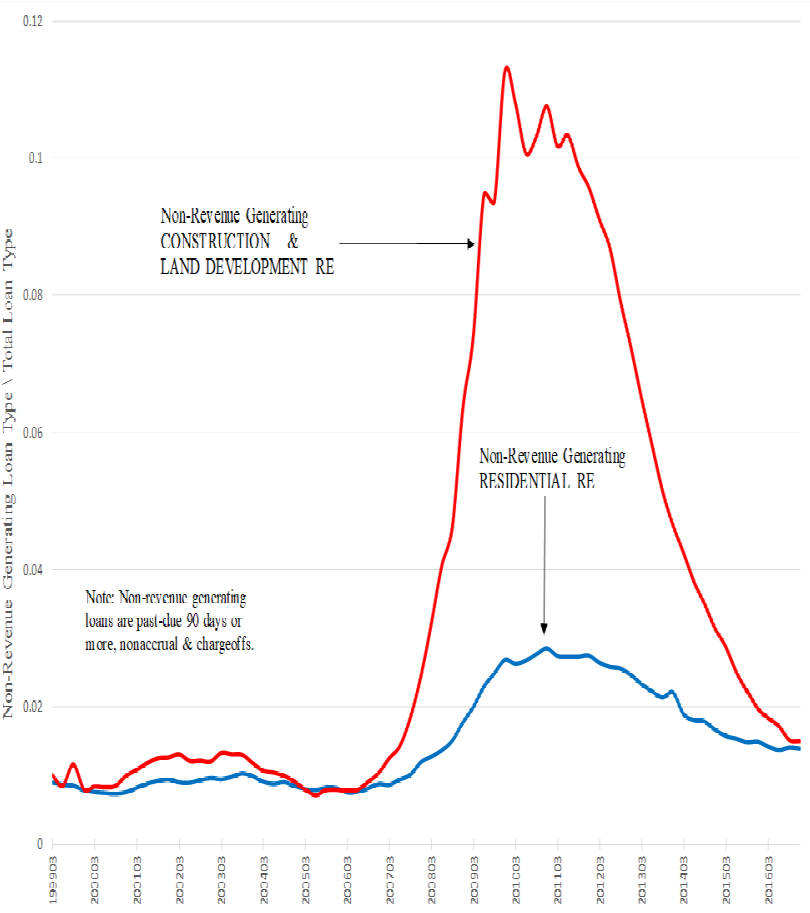

Figure 2: Average Non-Revenue Generating Residential and C\&D Loans as a Proportion of the Loan Category (Source: FDIC, Bank Reports of Income and Condition, various years).

The residential house price changes also could have large effects on the repayments of construction and land development (C\&D) loans that were made by banks scaled by their total assets (recon) as shown in Figure 3. The links between the residential and commercial real estate markets is discussed recently in D'Erasmo [4] and Antoniades [5]. When the house price changes declined the loan repayments also declined as many house construction projects became less profitable and more of them had to be charged off. As shown in Figure 2, the non-revenue generating C\&D loans averaged $11 \%$ of these loans in the 2009Q4-2010Q4 period that is computed from the individual bank Call Reports. ${ }^{2}$ Its peak value over this period is 3 times larger than the 2000-2016 average value. Although a smaller portion of the average bank's asset size than residential lending, C\&D loans still comprised a large enough portion to cause problems for the bank when these loans are not revenue-generating and/or ultimately get charged off. The banking groups' average construction and land development lending portions of their assets were greatest over 2007-2009 in this Great Recession period. The largest portion of these loans is from the $\$ 1$ to $\$ 10$ billion groups with over $12 \%$, followed by the $\$ 100$ million to $\$ 1$ billion, the $\$ 10$ to $\$ 250$ billion, the under $\$ 100$ million, and the over $\$ 250$ billion banking groups in descending order. The

2 The non-revenue generating loan ratios developed in this paper and the non-current ratios presented in the FDIC Quarterly Banking Profile (QBP) differ primarily because the average ratios in the QBP are constructed from aggregate noncurrent loans divided by aggregate loan values. 
largest asset-size banking group had the smallest portion of their assets in C\&D loans at slightly over $2 \%$. In general, we note that the largest banks were more heavily involved with residential mortgage lending and banks with more moderate asset sizes had larger portions of their assets in construction and land development loans.

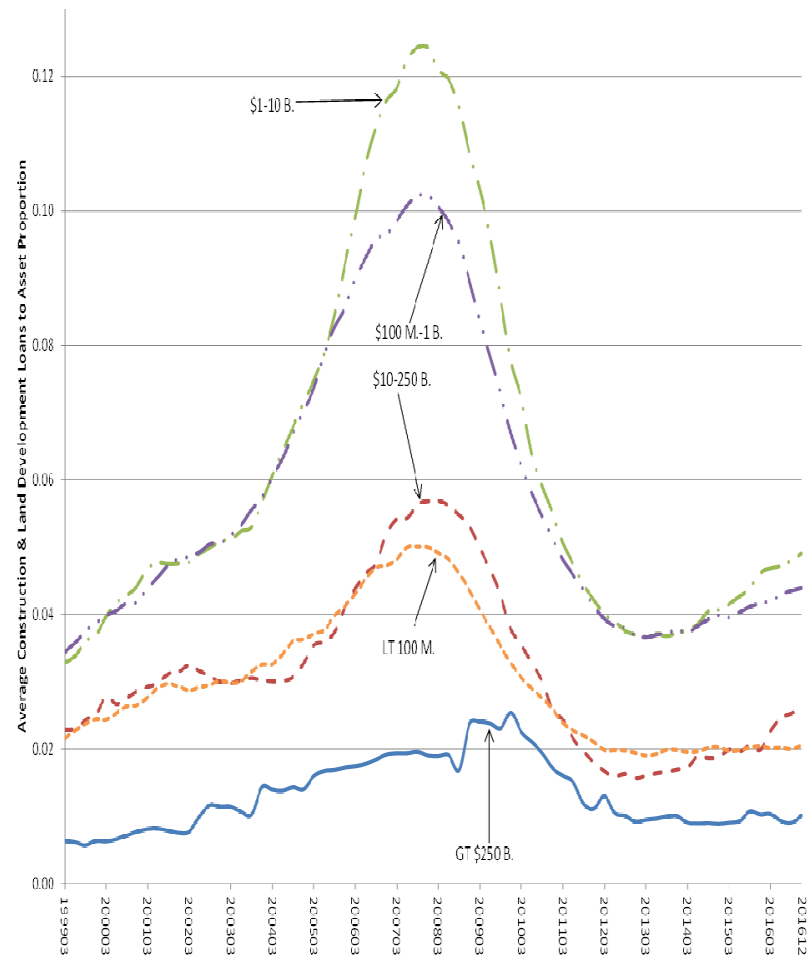

Figure 3: Average Construction \& Land Development Loan to Asset Proportion by Asset-Size Group (Source: FDIC, Bank Reports of Income and Condition, various years).

The decrease in residential house prices across the continental U.S., as shown in Figure 4, contradicts the established regulatory perspective that performing residential mortgage loans should receive a lower risk rating. The Federal Financial Institutions Examination Council (FFIEC) in December 2007 established that the bank-reported financial information weight the risk level of most performing first-lien mortgages at a maximum of $\$ 0.50$ for every $\$ 1.00$ of residential home lending. This risk rating is important to assign risk-weighted capital levels that banks must hold for these types of loans. For this reason, the lower risk assigned to first-lien residential mortgage loans required less capital to be kept for them. Over the 2005-2015 sample period, these loans are the vast majority of residential mortgage loans at $72 \%$, while the home equity lines of credit compose $22 \%$ and the second lien closed-end loans are $6 \%$.

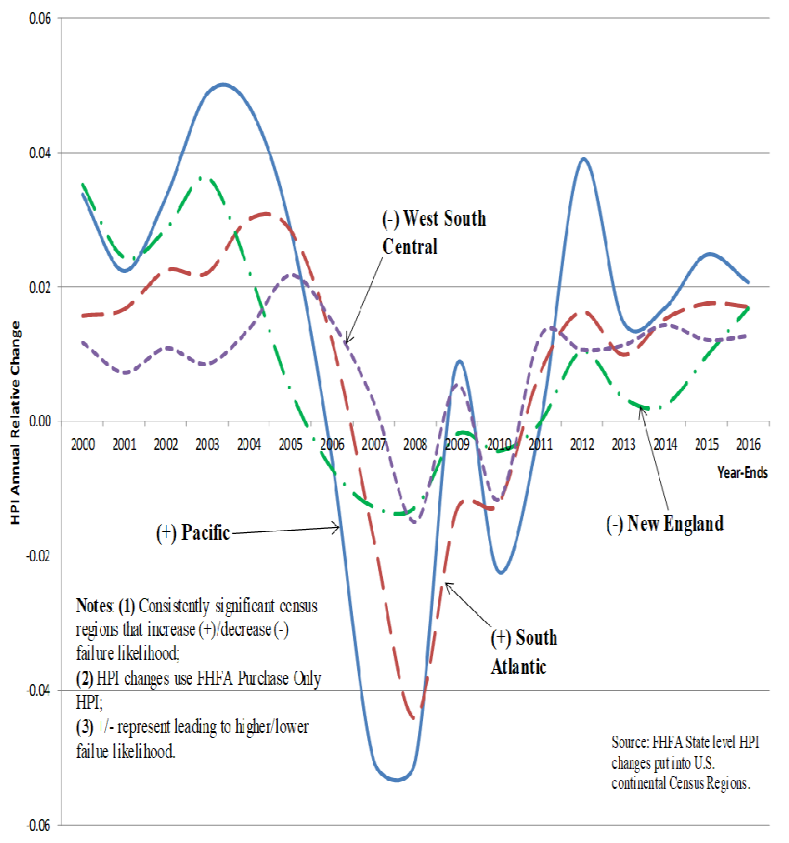

Figure 4: Consistently Significant FHFA Census Region HPI Change Values (Source: Federal Housing Finance Agency, https:/www.fhfa.gov/DataTools/Downloads/Pages/House-

Price-Index.aspx).

The Great Recession may have ended in the mid-year of 2009 (according to the NBER), but the effects of the bank failures and retarded lending of the banking system severely plagued the recovery. ${ }^{3}$ The financial crisis began in mid-2007 with the failure of Bear Stearns' hedge funds and it strengthened in the second half of 2008 when other large financial firms (including insured banks) failed or needed financial assistance. Some of these firms had large, global financial institutions at their center so that this crisis period contained the largest failed bank asset size in any period for the FDIC. The average failed bank asset size was the largest during the 2008-2009 period at $\$ 35$ billion and this contributed to the severity of the crisis and recession. Moreover, the regression analysis identifies that banks with larger asset sizes had higher likelihoods of failure relative to smaller banks over the early years of this crisis period. This period also gained public notice when some larger financially distressed banks received Open Bank Assistance (OBA) in 2008 and 2009.4 This financial distress among larger banks led to a stream of papers that discuss their practices involving nontraditional banking activities such as insurance underwriting, subprime lending and subprime mortgage securitizations. These papers include DeYoung, and Torna [6], Sanders [7], Gorton [8], and Gorton and Metrick [9].

3 The following NBER site contains the timing of these economic cycles in the U.S., https://www.nber.org/cycles/

4 See Open Bank Assistance, Chapter 5 of Federal Deposit Insurance Corporation, Managing the Crisis: the FDIC and RTC Experience 1980- 1994, (1998). 
This paper does not examine the more nontraditional banking activities as described above. Rather, it makes an important contribution to the literature by clearly identifying the significant and diverse impacts that regional residential HPI change-house loan interactions. These regional interactions demonstrate the large portions of bank lending simultaneously devoted to residential mortgage activity and the other bank financial condition factors jointly had over the Great Recession crisis period on the likelihoods of bank failures. We know that separate regions had different house prices changes and bank failure outcomes and we see that in our estimated marginal effects. We also link these residential house price changes to the health of construction and land development loans for banks. The previous literature that focuses on explaining the causes of bank failures over this crisis period do not capture the important element of regional residential house price changes. This paper is able to identify the disparate real estate value change effects of separate regions on bank failures.

The remainder of this paper is organized as follows. Section II discusses the data that is used in this study. Section III presents the methodology and statistical approach that provides the econometric model and the empirical results. Section IV presents the summary and conclusion.

\section{DATA}

This paper uses all FDIC-insured depository institutions for analysis that existed at least three years prior to the estimation period. Table 1 defines the twenty-five predictor variables and identifies the a priori relationship we expect from the regressions to the likelihood of bank failure. The FHFA statelevel residential HPI changes are used and then allotted into U.S. continental census regions (New England, Middle Atlantic, South Atlantic, East North Central, East South Central, West North Central, West South Central, Mountain, and Pacific) as shown in Figure 5. This use of this type of regional HPI change measurement creates more dynamic elements to their interactions with bank residential lending over this Great Recession period. Their expected signs cannot be predetermined since HPI change directions vary over the estimation periods and these interactions tend to be inversely related to the likelihood of bank failure, so the expected sign is ambiguous. The regional separation of the regional HPI change interaction variables assumes that banks' activities take place within the same census region as their home bank locations. This is typically true for most banks in our sample. Bank branches within the same region as the headquarter bank vary over the sample periods that range from $79 \%$ in 2005 to $67 \%$ in 2015. In addition, the branches that performed deposit-taking intermediation activities were primarily located in the same region for the smaller banks under $\$ 10$ billion ( 97 $\%$ over the 2005-2015 period) and mostly in the same region for the larger banks (54\% over the same period). ${ }^{5}$ The statelevel real GDP relative change (realgdpchg) is added to the independent variables to account for larger-scale economic changes that occurred in each state and is assigned to the state in which the bank headquarters is located. Like the regional HPI change variables, the likelihood of failure for banks varies inversely with the state GDP change and its expected sign is ambiguous for the same reason. We use a dummy variable for banks that are at least $\$ 10$ billion to identify larger banks in the sample. This size measure is used because the Dodd-Frank Wall Street Reform and Customer Protection Act of 2010 established larger banks with at least this asset size conduct and report internal stress tests to their federal regulator. This dummy variable (asset_ge10B) is used in the estimation to determine whether large banks had higher or lower failure likelihoods. The variable is included to account for banks with large-scale diversification, economies of scale and scope, access to the capital markets, and an overall source of support for the entire organization - all factors that should reduce the likelihood of failure $(\beta<0)$. However, this bank size dummy variable is very significantly positive for both the 2008 (Table 3) and 2009 (Table 4) bank failure estimation period that indicates that these larger banks had higher likelihoods of failure. This may be partially explained by the fact that many more failures were of larger banks in 2008 and 2009 than in later or earlier years that were in the sample as failed or OBA banks. Total book equity to assets (the twelfth variable, te) begins the Call Report financial variables that are usually contained in traditional bank failure models.

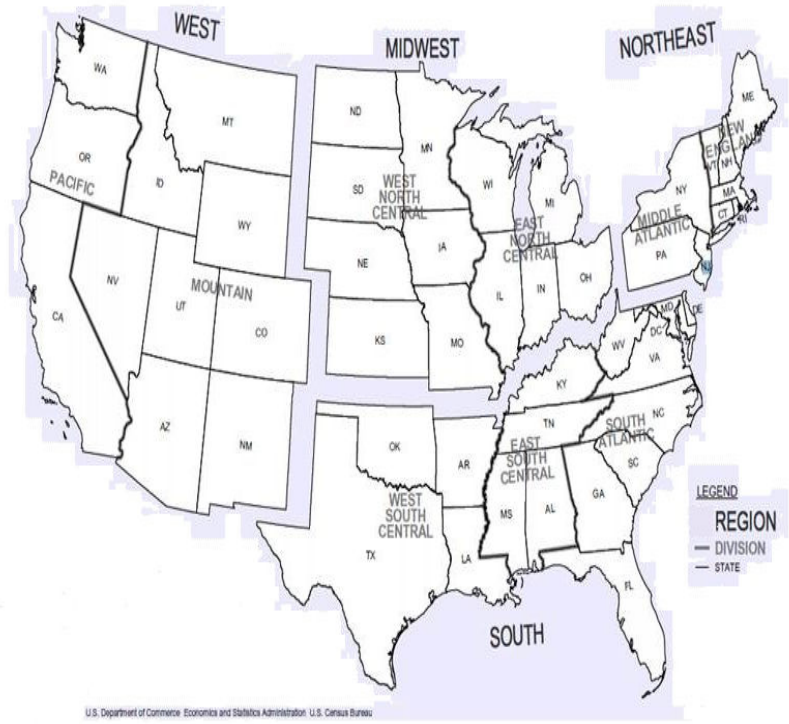

Figure 5: Census Regions in the Continental United States.

5 These statistics are derived from the FDIC Summary of Deposits database. 


\begin{tabular}{|c|c|c|}
\hline Variable & Description & $\begin{array}{l}\text { Expected Sign on } \\
\text { Failure Likelihood }\end{array}$ \\
\hline rrechg_ma_rer14 & $\begin{array}{l}\text { Interaction between FHFA residential HPI annual relative changes for the } \\
\text { Middle Atlantic census region \& 1-4 family residential loans. }\end{array}$ & Ambiguous \\
\hline rrechg_sa_rer14 & $\begin{array}{l}\text { Interaction between FHFA residential HPI annual relative changes for the } \\
\text { South Atlantic census region \& 1-4 family residential loans. }\end{array}$ & Ambiguous \\
\hline rrechg_mt_rer14 & $\begin{array}{l}\text { Interaction between FHFA residential HPI annual relative changes for the } \\
\text { Mountain census region \& 1-4 family residential loans. }\end{array}$ & Ambiguous \\
\hline rrechg_pac_rer14 & $\begin{array}{l}\text { Interaction between FHFA residential HPI annual relative changes for the } \\
\text { Pacific census region \& 1-4 family residential loans. }\end{array}$ & Ambiguous \\
\hline rrechg ne rer14 & $\begin{array}{l}\text { Interaction between FHFA residential HPI annual relative changes for the } \\
\text { New England census region \& } 1-4 \text { family residential loans. }\end{array}$ & Ambiguous \\
\hline rrechg_enc_rer14 & $\begin{array}{l}\text { Interaction between FHFA residential HPI annual relative changes for the East } \\
\text { North Central census region \& 1-4 family residential loans. }\end{array}$ & Ambiguous \\
\hline rrechg_esc_rer14 & $\begin{array}{l}\text { Interaction between FHFA residential HPI annual relative changes for the East } \\
\text { South Central census region \& 1-4 family residential loans. }\end{array}$ & Ambiguous \\
\hline rrechg_wsc_rer14 & $\begin{array}{l}\text { Interaction between FHFA residential HPI annual relative changes for the } \\
\text { West South Central census region \& 1-4 family residential loans. }\end{array}$ & Ambiguous \\
\hline rrechg_wnc_rer14 & $\begin{array}{l}\text { Interaction between FHFA residential HPI annual relative changes for the } \\
\text { West North Central census region \& 1-4 family residential loans. }\end{array}$ & Ambiguous \\
\hline realgdpchg & State real GDP annual relative change. & - \\
\hline asset_ge10B & Dummy for asset level of at least $\$ 10$ billion. & - \\
\hline te & Total book equity volume. & - \\
\hline $11 \mathrm{r}$ & Asset loss reserves for loan, leases \& bank's securities. & - \\
\hline roa & Return on assets is the annualized net bank income. & - \\
\hline npap_lnlsdebt & $\begin{array}{l}\text { Non-performing assets are loans, leases \& bank's securities that have past-due } \\
\& \text { nonaccrual repayment statuses, and other real estate owned balances. }\end{array}$ & + \\
\hline sec & Securities held to maturity plus securities held for sale. & - \\
\hline bd & $\begin{array}{l}\text { Brokered deposits are deposit liabilities typically raised through national } \\
\text { brokers rather than local customers. }\end{array}$ & or + - \\
\hline cashdue & Total cash \& balances due from depository institutions. & - \\
\hline goodwill & Goodwill intangible assets. & + \\
\hline rer14 & Loans secured by $1-4$ family residential properties. & - \\
\hline remul & Loans secured by multi-family (more than 5) residential properties. & + \\
\hline recon & Loans for construction or land development secured by these properties. & + \\
\hline recom & $\begin{array}{l}\text { Loans to finance commercial real estate, construction \& land development not } \\
\text { secured by real estate. }\end{array}$ & + \\
\hline ci & Loans for commercial \& industrial purposes. & - \\
\hline cons & Loans to individuals for household \& personal expenditures. & - \\
\hline
\end{tabular}

Table 1: FHFA HPI and Call Report Variable Definitions.

Previous studies have shown that bank examination ratings can become outdated quickly [10]. This can also be said as well for past financial variables. We expect that the greater the age of the prior financial data in terms of lagged variables, the more likely there will be a less significance in these variables. However, analysis of these earlier data on current bank failures indicates how long in advance banks may be considered to be a possible failure or survivor 1, 2 or 3 years in the future. The bank-reported financial variables are accounting information that is included in the regressions to measure their financial condition. These variables are scaled by dividing by total assets.
The residential HPI changes are calculated from year-end Federal Housing Finance Agency (FHFA) residential HPI relative annual changes of purchase-only housing transactions for each census region. ${ }^{6}$ These HPI variables are calculated as annual relative changes as in (1):

6 The Federal Housing Finance Association residential housing price index (HPI) is the quarterly Purchase Only (from Sales Price data) that is seasonally adjusted. The base for these regional HPI values is 1991Q1. The HPI is a broad measure of the annual movement of single-family house price 
Regtonal HPI Change $e_{y t}=\delta_{i j t} \times\left(\frac{\text { Residentiai } H P I_{i j t}-{\text { Residential } H P I_{i j t-1}}_{1}}{\text { Restdenttal } H F I_{i j t-1}}\right)$

for each bank $i$ where $\delta$ is a regional dummy variable that is 1 if a bank's home is in that region and 0 otherwise, $\mathrm{j}$ is each of the 9 U.S. Census regions, and $\mathrm{t}=2005 \mathrm{q} 4,2006 \mathrm{q} 4, \ldots \ldots$, $2015 \mathrm{q} 4$ where the time periods are listed as year-end quarters. These Regional HPI change variables are put into a series of cross-section regressions shown in equation (2) of the following Econometric Model subsection. Note that this Regional HPI variable combines both the regional locations effects and the effects of HPI rates of change on bank failures. ${ }^{7}$ The regional HPI change-house loan interaction variables are the residential real estate loan volume divided by asset ratio multiplied by the regional residential HPI change variables shown in equation (1).

Given the dramatic declines in residential relative HPI changes across U.S. housing markets from 2006 to 2011 (Figure 4) after which rates of change began to increase, their interactions with residential home loans are significant explanations of bank failures by census region. Separate effects are generated for each census region because these house price movements are local and very different across regions. The model estimates the probability of bank failure at the year in question. Previous studies that use HPI changes do so by collapsing them into a single variable. We specify nine regional HPI change variables to capture more local residential house market effects on the financial conditions in different regions of the U.S. to separately identify the effects of these changes on residential home loans held by banks. Indeed, we can see that the large declines in home prices from 2008q4 $2011 q 4$ occurred particularly in the South Atlantic and Pacific regions and they subsequently recovered. ${ }^{8}$

\section{METHODOLOGY}

AND

\section{STATISTICAL APPROACH}

In modeling bank failures, the dependent variable FAIL is binary (fail (1) or survive (0)). Our model is a logistic regression that produces odds-ratio estimates of failure and survival, as well as the mean marginal effects of these estimates. These bank failures are taken for each year over the 2008 - 2015 period, and the independent variables are used to estimate one through five year-end lags from the bank failure year. We limit the modeling to these years since there were few failures from 2003 to 2007 with the largest number of

changes. The HPI is a weighted, repeat-sales index, meaning that it measures average price changes in repeat sales on the same properties. This information is obtained by reviewing repeat mortgage transactions on single-family properties whose mortgages have been purchased or securitized by Fannie Mae or Freddie Mac since January 1975.

7 This approach is used rather than one that would create a variable of the HPI change for each banks' region as one variable that have been used in other papers.

8 The website for the FHFA HPI Purchase only data is: https://www.fhfa.gov/ failures being 4 in 2004 (Figure 6). In this way, the bank failure regressions are a series of cross-sectional logistic regressions for each failure year. Our approach is similar to the one used by Cole and White [1] with the exception of the inclusion of regional annual house price changes. It should be noted that the cross-sectional samples for each failure differ in terms of both the composition of banks and the financial conditions, so each regression indicates the likelihood of failure for that sample and set of conditions.

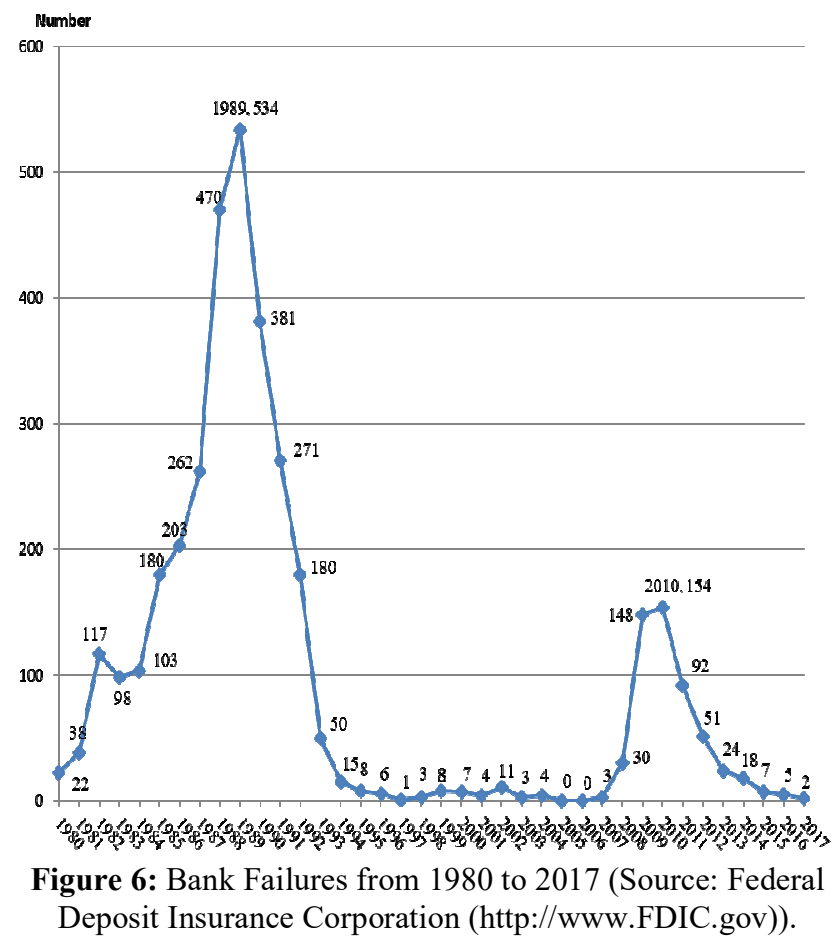

The census regional residential HPI change interaction variables with residential home loans that we utilize are components that have not been used in previous bank failure estimations as separate regional effects. We use census regional HPI change variables based their state-level values highlight their locational effects; having a unique estimation variable for each census region identifies the effects of HPI change on residential house loans made have on bank failures for that region.

These effects on financially distressed banks are directly and indirectly linked. That is, a direct link is the decline in these HPI interaction variable can lead to events like mortgage delinquencies and foreclosures on banks' balance sheets that ultimately lead to bank losses and potential failure. Even in post-2011 period when most regional residential HPI values are increasing (Figure 4) and residential house loans are decreasing by most banks (Figure 6), the volume of mortgage lending relative to a property value can still have a negative effect on a bank's financial health when a mortgagor has payment delinquencies and defaults. In addition, home builders and developers are sensitive to house price changes 
since these changes will affect their ability to sell newly built houses and other business real estate. Declining house prices may lead builders and developers to abandon projects, experience declines in cash flow and lead them to default on their bank borrowings. The decline in these regional HPI change-house loan interactive variables have negative impacts on banks' financial well-being.

For our empirical study, we consider the bank sample to be commercial banks, savings banks and savings \& loan institutions that are insured by the FDIC. Bank failures include banks that are closed by their federal supervisory agency and resolved by the FDIC for disposition or allowed to remain operating with federal government assistance (OBA). ${ }^{9}$ In addition to these failed and OBA banks, we also include in this sample banks that have negative net book equity after including reserves and assuming $50 \%$ of their nonperforming assets go to default. ${ }^{10} \mathrm{We}$ label these banks as technical failures. These technical failure banks are used for every sample period when they are active and contain negative net book equity values. We are studying financially distressed banks on a continuum from failed, technically failed and survivors.

The approach to bank failure modeling is that once a bank is declared to be disposed of by the FDIC it will remain in that failure state whereas ongoing banks including those that receive OBA and technical failures can continue operating and may change this status within the next year. Many assisted and technical failure banks survive and will show up in the sample of surviving banks in later years, and surviving banks in one year may change state in later years also. This process has two supervisory outcomes and is consistent with a logistic estimation procedure [11]. Once a bank is determined to be actually failed it drops out of the sample (unlike the many OBA banks that survived and technical failures) and will not appear in the following banking samples.

\subsection{Econometric Model}

We estimate a logistic model and use it to forecast bank failures and survival conditioned on institution size, bank financial failure components, and regional HPI change-house loan interaction factors. These variables are from one to three year-ends preceding each bank's year of failure and survivor banks from that same period. The financial components are bank-reported variables that indicate its financial health. As a group, they are proxies for components used by federal bank regulators to evaluate and rate bank financial health-Capital adequacy, Asset Quality, Management, Earning, Liquidity, and Sensitivity to Market Risk (CAMELS). For example, a bank that has a greater amount of capital, lower

9 Banks that participated in TARP or any special FDIC programs (like the Temporary Liquidity Guarantee Program) or Federal Reserve facilities during the Great Recession period does not qualify them as receiving OBA.

10 The net book equity formula is the following: Capitalt + Reservest - 0.5(Non-Performing Assetst + Non-Accrual Assetst). See Cole \& White (2011). nonperforming assets, good management, higher earnings and greater access to funding has a lower probability of failure. This model includes regional residential HPI change-house loan interactions to account for banks' exposures to movements in housing prices for each census region. ${ }^{11}$ Given the dramatic declines in residential house prices across U.S. housing markets during the Great Recession period, these factors are considered to be significant explanations of bank failures from different census regions. The model estimates the probability of bank failure in the year in question by using series of cross-section regressions with 1 to 3 year differences between failure year and the explanatory variables. Estimated marginal effects are derived from the regression estimated coefficients and measured at the means of the included variables for each of the respective sample periods. We assume the unobserved underlying response variable, Yit, is a linear function as in (2):

$Y_{\mathrm{it}}=\alpha_{1}+\sum_{\mathrm{j}=1}^{9} M E_{1 \mathrm{j}}($ Regional HPI Chg.-House Loan
Interaction $\left._{\mathrm{ij}(\mathrm{t}-\mathrm{v}) \mathrm{q} 4}\right)+M E_{110}\left(\right.$ Real GDP Chg. $\left.{ }_{\mathrm{i}(\mathrm{t}-\mathrm{v}) \mathrm{q} 4}\right)+$
$M E_{111}$ (Asset_ge10B ${ }_{\mathrm{i}(\mathrm{t}-\mathrm{v}) \mathrm{q} 4)}+\sum_{\mathrm{i}=12}^{25} M E_{2 \mathrm{j}}($ Financial Failure

Variables $\left._{\mathrm{ij}(\mathrm{t}-\mathrm{v}) \mathrm{q} 4}\right)+\varepsilon_{\mathrm{it}}$

for each bank (i) where the $\mathrm{ME}_{1 \mathrm{j}}=1, \ldots 11$ are the marginal effects for the FHFA residential relative change interactions with residential house loans in each census region, the real GDP change, and the large bank (at least $\$ 10$ Billion) indicator variable; $\mathrm{ME}_{2 \mathrm{j}}=12, \ldots 25$, are marginal effects for bank financial variables that are proxies of the component CAMELS ratings of bank condition; $t$ are failure years for the dependent variable where $\mathrm{t}=2008,2009, \ldots, 2015$; $(\mathrm{t}-\mathrm{v}) \mathrm{q} 4$ are the covariate dates that are the year-end quarter of the preceding years where $\mathrm{v}=1, \ldots, 3$ to represent the one- to three-year lags in the regressions. The theoretic background to this binary logistic model is as follows. The $\varepsilon_{\text {it }}$ errors are assumed to have a cumulative logistic function that is similar for each group - failure or survivor - [11]. We estimate the single constant terms $(\alpha 1)$ under the assumption that the proportional odds among the groups are independent of the explanatory variables such that the slope parameters are the same for each group. In general, to separate the failed from the survivor group requires a single plane and more for more than two dimensions. We designate group 1 institutions as failures and group 0 as surviving institutions in the year of observation. In practical terms, this means that the probability of an observation i belonging to failed banks (group 1), conditional on the regressors, is $F\left(\alpha_{1}+\beta^{\prime} X_{i}\right)$; the conditional probability of its belonging to non-failed banks (group 0 ) is 1 $-\mathrm{F}\left(\alpha_{1}+\beta^{\prime} \mathrm{X}_{\mathrm{i}}\right)$ where $\alpha_{1}$ is the estimated intercept term, $\beta$ is a vector of estimated coefficients for the logistic regression and $\mathrm{F}()$ is the cumulative logistic function.

11 We use nested likelihood ratio tests to find that the inclusion of HPI change-house mortgage loan interactions significantly increase the explanatory power for $42 \%$ of the regression model comparisons. The base model has the regional HPI changes and bank-reported financial variables. 
We report the marginal effects of each variable rather than the actual estimated coefficients. The marginal effect evaluated at a particular point provides the degree that a change in the respective variable contributes to the likelihood of bank failure (a positive sign) or survival (a negative sign). These effects are then evaluated by taking the product of each variable value at its sample mean and its estimated mean marginal effect; where this is shown by the ME-Mean effect. This is equivalent to specifying all other variables are held constant at their overall sample mean values. When the coefficient is negative it identifies that the variable reverses the failure effect that the value that it is evaluated. The direction of the ME-Mean effect for the bank-reported Call Report financial variables is the same as the reported marginal effect because their mean values are positive. The significance level of the estimated parameter is also reported and can be interpreted as the significance of the marginal effect of the variable that is changed. ${ }^{12}$

Figure 4 shows the regional HPI relative changes that are consistently significant to explain bank failures for most of the logistic regressions in two or more sample years. These census regions include the South Atlantic and Pacific that have higher likelihoods of failure for the regional residential HPI changehouse loan interactions and shows large decreases in HPI changes over the 2005 - 2008 period. Also, the West North Central region also has higher failure likelihoods for these interactions in 2010 and 2011 failures where its HPI changes are moderately significant. The New England and West South Central regions have significant lower failure likelihood effects for the residential HPI changes and loan interactions over most of the 2008 - 2015 period where their HPI changes fluctuate but remain more stable. Their effects on bank failures can be seen by the regression results that are discussed in the next section.

Table 2 shows the difference in the regression variable values between the five years of 2008q4 and 2013q4. Most of the regional residential HPI annual relative change and residential loan interactions reached their troughs at year-end 2008 and were recovering by 2013. All of these regional residential HPI annual change interactions have positive and highly significant mean differences. ${ }^{13}$ Just based on these relative change differences in 2013q4 compared to 2008q4, the South Atlantic (rrechg_sa_rer14), Pacific (rrechg_pac_rer14) and New England (rrechg_ne_rer14) regions are the largest differences. For the bank-reported variable differences, it is interesting that while banks' earnings (roa) and capital (te) levels increased in $2013 q 4$ relative to $2008 \mathrm{q} 4$, their main lending areas (rer14, recon, ci, cons) decreased.

\footnotetext{
12 This is only an approximation at large samples sizes. In our case the sample size for each regression between 7,992 and 6,261 that can normally be considered large sample sizes particularly since they include the universe of banks for each year.

${ }^{13}$ The mean differences are $2013 \mathrm{q} 4$ values $-2008 \mathrm{q} 4$ values.
} 


\begin{tabular}{|c|c|c|c|c|c|c|c|c|}
\hline & \multicolumn{3}{|c|}{ Statistics Data 2008Q4 } & \multicolumn{3}{|c|}{ Statistics Data 2013Q4 } & \multicolumn{2}{|c|}{ 2013Q4 - 2008Q } \\
\hline & $\mathbf{N}$ & Mean & Std. Dev. & $\mathbf{N}$ & Mean & Std. Dev. & Difference & t-test \\
\hline \multicolumn{9}{|c|}{ FHFA HPI, GDP \& Asset-size Variables } \\
\hline rrechg_ma_rer14 & 475 & -0.016458 & 0.012333 & 454 & 0.008335 & 0.005730 & 0.024793 & $* * *$ \\
\hline rrechg_sa_rer14 & 908 & -0.030829 & 0.030099 & 804 & 0.014752 & 0.012642 & 0.045581 & $* * *$ \\
\hline rrechg_mt_rer14 & 401 & -0.011211 & 0.018558 & 329 & 0.008817 & 0.009803 & 0.020028 & $* * *$ \\
\hline rrechg_pac_rer14 & 314 & -0.022864 & 0.030497 & 301 & 0.016371 & 0.017459 & 0.039235 & $* * *$ \\
\hline rrechg_ne_rer14 & 243 & -0.025259 & 0.013311 & 214 & 0.013200 & 0.010125 & 0.038459 & $* * *$ \\
\hline rrechg_enc_rer14 & 1,437 & -0.018598 & 0.013428 & 1,275 & 0.011903 & 0.007986 & 0.030501 & $* * *$ \\
\hline rrechg_esc_rer14 & 595 & -0.008601 & 0.004899 & 582 & 0.007295 & 0.005137 & 0.015896 & $* * *$ \\
\hline rrechg_wsc_rer14 & 1,138 & -0.003712 & 0.003671 & 1,019 & 0.007033 & 0.006384 & 0.010745 & $* * *$ \\
\hline rrechg_wnc_rer14 & 1,869 & -0.006503 & 0.008585 & 1,650 & 0.005473 & 0.004991 & 0.011976 & $* * *$ \\
\hline realgdpchg & 7,507 & -0.023263 & 0.034241 & 6,657 & 0.026047 & 0.013929 & 0.049310 & $* * *$ \\
\hline asset_ge 10B & 7,536 & 0.013137 & 0.113869 & 6,683 & 0.014365 & 0.118998 & 0.001228 & \\
\hline \multicolumn{9}{|c|}{ Call Report Variables } \\
\hline te & 7,380 & 0.108832 & 0.055220 & 6,333 & 0.110840 & 0.053390 & 0.002008 & $* *$ \\
\hline $11 \mathrm{r}$ & 7,380 & 0.009503 & 0.006600 & 6,333 & 0.009925 & 0.005940 & 0.000422 & $* * *$ \\
\hline roa & 7,380 & 0.004055 & 0.030190 & 6,333 & 0.007662 & 0.063020 & 0.003607 & $* * *$ \\
\hline npap_lnlsdebt & 7,380 & 0.031216 & 0.035400 & 6,333 & 0.024465 & 0.029940 & -0.006751 & $* * *$ \\
\hline $\mathrm{sec}$ & 7,380 & 0.201803 & 0.148610 & 6,333 & 0.237612 & 0.163420 & 0.035809 & $* * *$ \\
\hline bd & 7,380 & 0.039278 & 0.083920 & 6,333 & 0.019260 & 0.049760 & -0.020018 & $* * *$ \\
\hline cashdue & 7,380 & 0.057141 & 0.065740 & 6,333 & 0.099805 & 0.093910 & 0.042664 & $* * *$ \\
\hline goodwill & 7,380 & 0.004922 & 0.018740 & 6,333 & 0.003020 & 0.013250 & -0.001902 & $* * *$ \\
\hline rer14 & 7,380 & 0.207768 & 0.157900 & 6,333 & 0.183331 & 0.138190 & -0.024437 & $* * *$ \\
\hline remul & 7,380 & 0.015878 & 0.033110 & 6,333 & 0.019852 & 0.037640 & 0.003974 & $* * *$ \\
\hline recon & 7,380 & 0.069194 & 0.079280 & 6,333 & 0.032743 & 0.034470 & -0.036451 & $* * *$ \\
\hline recom & 7,380 & 0.153179 & 0.112780 & 6,333 & 0.158694 & 0.119860 & 0.005515 & $* * *$ \\
\hline ci & 7,380 & 0.088351 & 0.069430 & 6,333 & 0.078351 & 0.065280 & -0.010000 & $* * *$ \\
\hline cons & 7,380 & 0.043093 & 0.054210 & 6,333 & 0.030941 & 0.044030 & -0.012152 & $* * *$ \\
\hline
\end{tabular}

Notes: (1) Values for each variable are measured at each time period and taken from the sample;

(2) $* * *$ is $1 \%, * *$ is $5 \%$ and $*$ is $10 \%$ significance.

Table 2: Statistical Comparison of 2008q4 and 2013q4.

\subsection{Empirical Results}

Tables 3-7 present the estimated marginal effects for failure years 2008, 2009, 2010, 2012, and 2014. Appendix A contains Tables A1 through A3 that show these estimates for failure years 2011, 2013 and 2015. They show the explanatory effects of the variables on bank failures over the one-, two- and threeyear gaps between the failure year and explanatory variables. The marginal effects are evaluated at the variables' mean values. We examine each failure year separately. For the 2008 failures (Table 3), the Pacific (rrechg_pac_rer14) region shows a significant interaction effect with positive ME-Mean effects for the one- and three-year gaps. The one-year gap (independent variable in 2007q4) coefficient is negative and the mean interaction value is also negative due to the falling HPI changes in the Pacific region. Its three-year gap coefficient is positive and more marginally significant when 
the interaction mean value is also positive in $2005 q 4$ when the HPI change is positive. It is interesting that its two-gap MEMean value is negative and its coefficient is marginally significant for $2006 \mathrm{q} 4$ when there were transitions from rising to falling residential house prices. The South Atlantic (rrechg_sa_rer14) and Mountain (rrechg_mt_rer14) regions have significant interaction coefficients with positive MEMean values in the one-year gap that explain higher

\begin{tabular}{|c|c|c|c|c|c|c|}
\hline \multirow{4}{*}{ rrechg_ma_rer14 } & \multicolumn{2}{|c|}{ F 2008 - IV 2007Q4 } & \multicolumn{2}{|c|}{ F 2008 - IV 2006Q4 } & \multicolumn{2}{|c|}{ F 2008 - IV 2005Q4 } \\
\hline & $\mathbf{M E} / \mathbf{p}^{1}$ & Mean & $\mathbf{M E} / \mathbf{p}^{1}$ & Mean & $\mathrm{ME} / \mathbf{p}^{1}$ & Mean \\
\hline & -0.011803 & 0.000428 & -0.780155 & 0.008762 & -0.157383 & 0.030372 \\
\hline & 0.842 & & 0.139 & & 0.158 & \\
\hline \multirow{2}{*}{ rrechg_sa_rer14 } & -0.052254 & -0.005864 & 0.022082 & 0.011153 & 0.046037 & 0.033398 \\
\hline & $0.000 * * *$ & & 0.508 & & 0.103 & \\
\hline \multirow[t]{2}{*}{ rrechg_mt_rer14 } & -0.069917 & -0.00061 & -0.071170 & 0.009135 & 0.026362 & 0.016002 \\
\hline & $0.004 * * *$ & & 0.430 & & 0.503 & \\
\hline \multirow[t]{2}{*}{ rrechg_pac_rer14 } & -0.028509 & -0.008015 & -0.117034 & 0.003717 & 0.060770 & 0.021030 \\
\hline & $0.08 *$ & & 0.69 & & $0.080 *$ & \\
\hline \multirow[t]{2}{*}{ rrechg_ne_rer14 } & -0.049402 & -0.008805 & 0.039112 & -0.00767 & -0.203206 & 0.022913 \\
\hline & 0.447 & & 0.410 & & 0.280 & \\
\hline \multirow[t]{2}{*}{ rrechg_enc_rer14 } & 0.006622 & -0.006105 & 0.010675 & 0.002316 & -0.005316 & 0.011363 \\
\hline & 0.882 & & 0.849 & & 0.965 & \\
\hline \multirow{2}{*}{ rrechg_esc_rer14 } & -0.058324 & 0.003584 & -0.143805 & 0.01185 & -0.182073 & 0.015387 \\
\hline & 0.771 & & 0.257 & & 0.377 & \\
\hline \multirow[t]{2}{*}{ rrechg_wsc_rer14 } & -0.028199 & 0.00416 & -0.126951 & 0.008225 & -0.057935 & 0.007290 \\
\hline & 0.721 & & 0.344 & & 0.665 & \\
\hline \multirow[t]{2}{*}{ rrechg_wnc_rer14 } & -0.044816 & -0.000891 & 0.054752 & 0.003094 & 0.164020 & 0.007290 \\
\hline & 0.231 & & 0.484 & & 0.111 & \\
\hline \multirow[t]{2}{*}{ realgdpchg } & 0.009580 & 0.021039 & 0.009664 & 0.022977 & 0.012443 & 0.021892 \\
\hline & 0.258 & & 0.356 & & 0.680 & \\
\hline \multirow[t]{2}{*}{ asset_ge10B } & 0.001636 & 0.013484 & 0.003454 & 0.013020 & 0.007050 & 0.012871 \\
\hline & $0.007 * * *$ & & $0.001 * * *$ & & $0.000 * * *$ & \\
\hline \multirow[t]{2}{*}{ te } & -0.036946 & & -0.039372 & & -0.020521 & \\
\hline & $0.002 * * *$ & & $0.012 * *$ & & 0.225 & \\
\hline \multirow[t]{2}{*}{$11 \mathrm{r}$} & -0.057160 & & -0.172466 & & -0.284733 & \\
\hline & $0.089 *$ & & $0.032 * *$ & & 0.49 & \\
\hline \multirow[t]{2}{*}{ roa } & -0.022136 & & -0.002913 & & -0.035571 & \\
\hline & $0.001 * * *$ & & 0.880 & & 0.509 & \\
\hline \multirow[t]{2}{*}{ npap_lnlsdebt } & 0.045008 & & 0.083860 & & 0.114101 & \\
\hline & $0.000 * * *$ & & $0.000 * * *$ & & $0.000 * * *$ & \\
\hline sec & 0.001876 & & 0.000079 & & -0.000565 & \\
\hline & 0.449 & & 0.985 & & 0.936 & \\
\hline $\mathrm{bd}$ & 0.004126 & & 0.004829 & & 0.000263 & \\
\hline & $0.001 * * *$ & & $0.015 * *$ & & $0.001 * * *$ & \\
\hline cashdue & 0.003890 & & -0.003948 & & 0.008797 & \\
\hline & 0.144 & & 0.670 & & 0.409 & \\
\hline goodwill & 0.026455 & & 0.021574 & & 0.002576 & \\
\hline & 0.127 & & 0.289 & & 0.925 & \\
\hline rer14 & 0.000553 & & 0.004850 & & 0.001990 & \\
\hline & 0.808 & & 0.134 & & 0.772 & \\
\hline remul & 0.008271 & & 0.011810 & & 0.017639 & \\
\hline & $0.002 * * *$ & & $0.009 * * *$ & & $0.018 * *$ & \\
\hline recon & 0.009823 & & 0.021324 & & 0.037833 & \\
\hline & $0.000 * * *$ & & $0.000 * * *$ & & $0.000 * * *$ & \\
\hline Recom & -0.003482 & & 0.003002 & & -0.001799 & \\
\hline & 0.109 & & 0.368 & & 0.750 & \\
\hline $\mathrm{ci}$ & 0.004340 & & 0.004252 & & 0.005934 & \\
\hline & 0.144 & & 0.384 & & 0.485 & \\
\hline cons & 0.001205 & & -0.007399 & & -0.011628 & \\
\hline & 0.763 & & 0.465 & & 0.398 & \\
\hline constant $^{2}$ & -4.988067 & & -4.881000 & & -5.607614 & \\
\hline & $0.026 * *$ & & $0.006 * * *$ & & $0.000 * * *$ & \\
\hline Pseudo $\mathrm{R}^{2}$ & 0.551 & & 0.374 & & 0.288 & \\
\hline
\end{tabular}

likelihoods of failure for banks in those regions. These are the significant regional HPI change-house loan interaction variables and their ME-Mean values that show higher likelihoods of failure. The large bank dummy (asset_ge10B) marginal effects are positive and significant for all three regressions indicating that large banks have higher likelihoods of failure. 


\begin{tabular}{|c|c|c|c|c|}
\hline $\mathrm{BIC}$ & 702 & 864 & 942 & \\
\hline Chi Squared (df) & $330(25)$ & $339(25)$ & $310(25)$ & \\
\hline Model Significance $p$ & 0 & 0 & 0 & \\
\hline Bank Failures $^{3}$ & 98 & 93 & 91 & \\
\hline OBA Banks & 3 & 2 & 3 & \\
\hline Observations & 7,563 & 7,786 & 7,992 & \\
\hline
\end{tabular}

Table 3: Logistic Regression 2008 Failures Marginal Effects Estimation.

For Call Report variables in 2008 failure regressions, the book equity (te) and loan loss reserves (llr) have consistently negative and significant marginal effects on the likelihood of bank failure, and banks' annual net income (roa) is negative and significant only at the one-year gap. The non-performing assets (npap lnlsdebt), brokered deposits (bd), multiple family residential loans (remul) and construction and land development loans secured by real estate (recon) have positive and consistently significant effects that show higher likelihoods of failure.

\begin{tabular}{|c|c|c|c|c|c|c|}
\hline & \multicolumn{2}{|c|}{ F 2009 - IV 2008Q4 } & \multicolumn{2}{|c|}{ F 2009 - IV 2007Q4 } & \multicolumn{2}{|c|}{ F 2009 - IV 2006Q4 } \\
\hline & $\mathbf{M E} / \mathbf{p}^{1}$ & Mean & $\mathrm{ME} / \mathbf{p}^{1}$ & Mean & $\mathrm{ME} / \mathbf{p}^{1}$ & Mean \\
\hline \multirow[t]{2}{*}{ rrechg_ma_rer14 } & -0.003196 & -0.016458 & -0.060898 & 0.000428 & -0.628269 & 0.008762 \\
\hline & 0.856 & & 0.939 & & 0.261 & \\
\hline \multirow[t]{2}{*}{ rrechg_sa_rer14 } & -0.000453 & -0.030829 & -0.347523 & -0.005864 & 0.183134 & 0.011153 \\
\hline & 0.886 & & $0.000 * * *$ & & $0.094 *$ & \\
\hline \multirow[t]{2}{*}{ rrechg_mt_rer14 } & 0.000896 & -0.011211 & -0.198658 & -0.000610 & -0.291118 & 0.009135 \\
\hline & 0.811 & & 0.199 & & 0.297 & \\
\hline \multirow{2}{*}{ rrechg_pac_rer14 } & -0.006047 & -0.022864 & -0.118595 & -0.008015 & 0.174097 & 0.003717 \\
\hline & $0.098 *$ & & 0.123 & & 0.101 & \\
\hline \multirow[t]{2}{*}{ rrechg_ne_rer14 } & 0.0237157 & -0.025259 & 1.380335 & -0.008805 & 0.589120 & -0.007670 \\
\hline & 0.117 & & $0.000 * * *$ & & $0.000 * * *$ & \\
\hline \multirow[t]{2}{*}{ rrechg_enc_rer14 } & 0.003674 & -0.018598 & -0.173611 & -0.006105 & -0.240185 & 0.002316 \\
\hline & 0.626 & & 0.153 & & 0.296 & \\
\hline \multirow[t]{2}{*}{ rrechg_esc_rer14 } & 0.022294 & -0.008601 & -1.602691 & 0.003584 & -0.749122 & 0.011850 \\
\hline & 0.287 & & 0.107 & & $0.027 * *$ & \\
\hline \multirow[t]{2}{*}{ rrechg_wsc_rer14 } & 0.033566 & -0.003712 & -2.140950 & 0.004160 & -2.242663 & 0.008225 \\
\hline & 0.504 & & $0.011 * *$ & & $0.003 * * *$ & \\
\hline \multirow[t]{2}{*}{ rrechg_wnc_rer14 } & -0.006383 & -0.006503 & -0.373871 & -0.000891 & -0.832629 & 0.003094 \\
\hline & 0.422 & & 0.144 & & $0.076 *$ & \\
\hline \multirow[t]{2}{*}{ realgdpchg } & -0.005372 & -0.023263 & 0.012624 & 0.021039 & 0.069955 & 0.022977 \\
\hline & $0.001 * * *$ & & 0.673 & & $0.016 * *$ & \\
\hline \multirow[t]{2}{*}{ asset_ge10B } & 0.000513 & 0.013137 & 0.011159 & 0.013484 & 0.014547 & 0.013020 \\
\hline & $0.013 * *$ & & $0.001 * * *$ & & $0.000 * * *$ & \\
\hline \multirow[t]{2}{*}{ te } & -0.038137 & & -0.188190 & & -0.167787 & \\
\hline & $0.000 * * *$ & & $0.000 * * *$ & & $0.000 * * *$ & \\
\hline \multirow[t]{2}{*}{$11 \mathrm{r}$} & -0.016448 & & -0.190603 & & -0.583423 & \\
\hline & $0.021 * *$ & & 0.327 & & $0.012 * *$ & \\
\hline \multirow[t]{2}{*}{ roa } & -0.003731 & & -0.038725 & & -0.047933 & \\
\hline & $0.052 *$ & & 0.598 & & $0.000 * * *$ & \\
\hline \multirow[t]{2}{*}{ npap_lnlsdebt } & 0.014450 & & 0.157655 & & 0.238189 & \\
\hline & $0.000 * * *$ & & $0.000 * * *$ & & $0.000 * * *$ & \\
\hline \multirow[t]{2}{*}{$\sec$} & -0.002585 & & 0.006607 & & -0.004658 & \\
\hline & $0.000 * * *$ & & 0.462 & & 0.671 & \\
\hline \multirow[t]{2}{*}{$\mathrm{bd}$} & 0.000857 & & 0.028044 & & 0.024316 & \\
\hline & $0.006 * * *$ & & $0.000 * * *$ & & $0.001 * * *$ & \\
\hline \multirow[t]{2}{*}{ cashdue } & -0.001650 & & -0.013256 & & -0.025225 & \\
\hline & $0.022 * *$ & & 0.622 & & 0.434 & \\
\hline \multirow[t]{2}{*}{ goodwill } & 0.034370 & & 0.134136 & & 0.081518 & \\
\hline & $0.000 * * *$ & & $0.022 * *$ & & 0.148 & \\
\hline rer14 & -0.001001 & & 0.007570 & & 0.008678 & \\
\hline & 0.197 & & 0.360 & & 0.351 & \\
\hline remul & 0.001242 & & 0.058883 & & 0.060377 & \\
\hline & $0.063 *$ & & $0.000 * * *$ & & $0.000 * * *$ & \\
\hline recon & 0.003219 & & 0.083710 & & 0.095283 & \\
\hline & $0.000 * * *$ & & $0.000 * * *$ & & $0.000 * * *$ & \\
\hline recom & -0.000254 & & 0.013566 & & 0.015549 & \\
\hline & 0.634 & & 0.113 & & 0.102 & \\
\hline
\end{tabular}




\begin{tabular}{|c|c|c|c|c|}
\hline \multirow[t]{2}{*}{$\mathrm{ci}$} & -0.001467 & 0.007309 & 0.000196 & \\
\hline & $0.083 *$ & 0.529 & 0.989 & \\
\hline \multirow[t]{2}{*}{ cons } & -0.001379 & -0.021042 & -0.025664 & \\
\hline & 0.349 & 0.400 & 0.377 & \\
\hline \multirow[t]{2}{*}{ constant ${ }^{2}$} & 3.195227 & -3.744479 & -3.195766 & \\
\hline & $0.006^{* * *}$ & $0.000 * * *$ & $0.000 * * *$ & \\
\hline Pseudo $\mathrm{R}^{2}$ & 0.677 & 0.370 & 0.305 & \\
\hline BIC & 1056 & 1799 & 1923 & \\
\hline Chi Squared (df) & 471 & 504 & 541 & \\
\hline Model Significance $p$ & 0 & 0 & 0 & \\
\hline Bank Failures $^{3}$ & 307 & 294 & 283 & \\
\hline OBA Banks & 5 & 5 & 4 & \\
\hline Observations & 7,380 & 7,563 & 7,786 & \\
\hline
\end{tabular}

Table 4: Logistic Regression 2009 Failures Marginal Effects Estimation.

Bank failures in 2009 (Table 4), the peak year of actual failed bank assets at approximately $\$ 2$ trillion, show the continued relevance of regional HPI change-house loan interactions, real GDP change, large bank dummy, and selected Call Report variables to explain bank failures. The South Atlantic (rrechg_sa_rer14) and Pacific (rrechg_pac_rer14) regions have positive and consistently significant ME-Mean effects for higher failure likelihoods. The South Atlantic region is significant at the two- (2007q4 independent variable) and three- year (2006q4) gaps, while the Pacific region is significant at the one-year gap (2008q4) and slightly above the $10 \%$ significance level in the two- and three-year gaps. The New England (rrechg_ne_rer14) and West South Central (rrechg_wsc_rer14) regions have regional HPI change-house loan interactions that are consistently significant with negative ME-Mean effects that show lower likelihoods of failure in the two- and three-year gaps. The New England region has a negative ME-Mean interaction value at the one-year gap with an estimated coefficient that is slightly above the $10 \%$ level. Also, the East South Central (rrechg_esc_rer14) and West North Central (rrechg_wnc_rer14) regions have significant and negative ME-Mean effects in the three-year gap. The real GDP change (realgdpchg) ME-Mean effects are positive and significant in one- (2008q4) and three-year (2006q4) gaps while these mean real GDP changes were negative and positive in these respective gap periods. The large bank dummy variable is positive and significant in all regressions for 2009 failures. Once again, this period shows that larger banks have higher likelihoods for failure.

There are many Call Report variables that have positive and negative effects on the likelihood of bank failures in 2009. The book equity (te), loan loss reserves and net income variables all have negative and significant marginal effects on the likelihood of failure in two or more gap periods. Securities (sec), cash from banks (cashdue) and C\&I lending (ci) have negative and significant marginal effects in the one-year gap regression. Non-performing assets (npap_lnlsdebt), brokered deposits (bd), secured real estate loans for construction and land development (recon), and loans for multi-family real estate (remul) variables have significant positive marginal effects in all regressions in explaining bank failures. The intangible assets (goodwill) variable has positive and significant effects in the one- and two-year gap regressions.

Bank failures occurred in their largest number for 2010 following the Great Recession period and the regression for 2010 failures is shown in Table 5. The regional residential HPI change-house loan interaction variables have positive MEMean effects that show higher likelihoods of failure are the South Atlantic region that is significant in all three-year gap periods, the West North Central region that is significant in the three-year estimation gap and slightly above the $10 \%$ level in the other two gap regressions, and the Middle Atlantic region that is significant in the three-year gap regression. The real GDP change variable shows the ME-Mean effect to be positive and significant in the two-year estimation gap with the state-level GDP changes promoting higher likelihoods of bank failure. The large bank dummy variable has a significant and negative value in the first-year estimation gap regression showing that larger banks had lower estimated likelihoods of failure for this period. This is in contrast to the previous two failure year results and is consistent with many prior studies that have shown that larger banks have a significantly smaller chance of failure than smaller banks (Cole and White 2012 for one).

\begin{tabular}{|c|c|c|c|c|c|c|}
\hline & \multicolumn{2}{|c|}{ F 2010 - IV 2009Q4 } & \multicolumn{2}{|c|}{ F 2010 - IV 2008Q4 } & \multicolumn{2}{|c|}{ F 2008 - IV 2007Q4 } \\
\hline & ME/p $\mathbf{p}^{1}$ & Mean & $\mathbf{M E} / \mathbf{p}^{1}$ & Mean & $\mathrm{ME} / \mathrm{p}^{1}$ & Mean \\
\hline \multirow{2}{*}{ rrechg_ma_rer14 } & -0.005306 & -0.005424 & -0.085575 & -0.016458 & 2.248957 & 0.000428 \\
\hline & 0.864 & & 0.607 & & $0.011 * *$ & \\
\hline \multirow[t]{2}{*}{ rrechg_sa_rer14 } & -0.036475 & -0.008654 & -0.097806 & -0.030829 & -0.440028 & -0.005864 \\
\hline & $0.000 * * *$ & & $0.026 * *$ & & $0.000 * * *$ & \\
\hline \multirow{2}{*}{ rrechg_mt_rer14 } & 0.022025 & -0.003433 & 0.026311 & -0.011211 & -0.364795 & -0.000610 \\
\hline & 0.174 & & 0.863 & & 0.112 & \\
\hline \multirow[t]{2}{*}{ rrechg_pac_rer14 } & -0.036368 & -0.005239 & -0.056213 & -0.022864 & 0.050508 & -0.008015 \\
\hline & 0.215 & & 0.264 & & 0.819 & \\
\hline
\end{tabular}




\begin{tabular}{|c|c|c|c|c|c|c|}
\hline \multirow[t]{2}{*}{ rrechg_ne_rer14 } & 0.129471 & -0.006886 & 0.635284 & -0.025259 & 2.054658 & -0.008805 \\
\hline & $0.086 *$ & & 0.111 & & $0.000 * * *$ & \\
\hline \multirow[t]{2}{*}{ rrechg_enc_rer14 } & -0.015984 & -0.006628 & -0.041619 & -0.018598 & -0.052760 & -0.006105 \\
\hline & 0.476 & & 0.719 & & 0.796 & \\
\hline \multirow[t]{2}{*}{ rrechg_esc_rer14 } & -0.063282 & -0.002433 & 0.537533 & -0.008601 & -2.301408 & 0.003584 \\
\hline & 0.121 & & 0.132 & & $0.043 * *$ & \\
\hline \multirow[t]{2}{*}{ rrechg_wsc_rer14 } & -0.000939 & 0.001565 & 0.772632 & -0.003712 & -1.868088 & 0.004160 \\
\hline & 0.991 & & 0.199 & & 0.109 & \\
\hline \multirow{2}{*}{ rrechg_wnc_rer14 } & -0.086578 & -0.000915 & -0.222226 & -0.006503 & -0.693784 & -0.000891 \\
\hline & 0.104 & & 0.110 & & $0.077 *$ & \\
\hline \multirow{2}{*}{ realgdpchg } & 0.004421 & -0.001143 & -0.085277 & -0.023263 & -0.051504 & 0.021039 \\
\hline & 0.485 & & $0.002 * * *$ & & 0.271 & \\
\hline \multirow[t]{2}{*}{ asset_ge10B } & -0.002609 & 0.012569 & -0.010795 & 0.013137 & -0.013694 & 0.013484 \\
\hline & $0.000 * * *$ & & 0.324 & & 0.310 & \\
\hline \multirow[t]{2}{*}{ te } & -0.044855 & & -0.151244 & & -0.075791 & \\
\hline & $0.000 * * *$ & & $0.000 * * *$ & & $0.053 *$ & \\
\hline \multirow[t]{2}{*}{$11 \mathrm{r}$} & -0.057579 & & -0.155119 & & -0.388814 & \\
\hline & $0.000 * * *$ & & 0.193 & & 0.107 & \\
\hline \multirow[t]{2}{*}{ roa } & -0.032514 & & 0.035007 & & -0.068556 & \\
\hline & $0.000 * * *$ & & $0.003 * * *$ & & 0.197 & \\
\hline \multirow[t]{2}{*}{ npap_lnlsdebt } & 0.030774 & & 0.125515 & & 0.132900 & \\
\hline & $0.000 * * *$ & & $0.000 * * *$ & & $0.000 * * *$ & \\
\hline \multirow{2}{*}{$\mathrm{sec}$} & -0.000862 & & -0.023222 & & -0.017477 & \\
\hline & 0.688 & & $0.064 *$ & & 0.336 & \\
\hline \multirow[t]{2}{*}{ bd } & 0.000657 & & 0.013216 & & 0.022671 & \\
\hline & 0.555 & & $0.028 * *$ & & $0.026 * *$ & \\
\hline \multirow[t]{2}{*}{ cashdue } & -0.002102 & & -0.010270 & & 0.013463 & \\
\hline & 0.324 & & 0.698 & & 0.668 & \\
\hline \multirow[t]{2}{*}{ goodwill } & 0.024898 & & 0.061582 & & 0.000538 & \\
\hline & 0.321 & & 0.411 & & 0.994 & \\
\hline \multirow[t]{2}{*}{ rer14 } & 0.000576 & & 0.005084 & & 0.013592 & \\
\hline & 0.753 & & 0.663 & & 0.321 & \\
\hline \multirow[t]{2}{*}{ remul } & 0.002923 & & 0.037045 & & 0.067564 & \\
\hline & 0.210 & & $0.003 * * *$ & & $0.000 * * *$ & \\
\hline \multirow{2}{*}{ recon } & 0.006643 & & 0.071164 & & 0.104744 & \\
\hline & $0.005 * * *$ & & $0.000 * * *$ & & $0.000 * * *$ & \\
\hline \multirow[t]{2}{*}{ recom } & 0.001230 & & 0.028793 & & 0.049082 & \\
\hline & 0.530 & & $0.002 * * *$ & & $0.001 * * *$ & \\
\hline \multirow[t]{2}{*}{ ci } & 0.000992 & & 0.008036 & & 0.022117 & \\
\hline & 0.719 & & 0.518 & & 0.215 & \\
\hline cons & -0.001174 & & -0.026709 & & -0.017633 & \\
\hline & 0.743 & & 0.293 & & 0.595 & \\
\hline constant $t^{2}$ & -2.714496 & & -3.992642 & & -4.775178 & \\
\hline & 0.152 & & $0.000 * * *$ & & $0.000 * * *$ & \\
\hline Pseudo $\mathrm{R}^{2}$ & 0.740 & & 0.354 & & 0.273 & \\
\hline $\mathrm{BIC}$ & 899 & & 1849 & & 2002 & \\
\hline Chi Squared (df) & $419(25)$ & & $469(25)$ & & $534(25)$ & \\
\hline Model Significance $p$ & 0 & & 0 & & 0 & \\
\hline Bank Failures $^{3}$ & 312 & & 299 & & 286 & \\
\hline OBA Banks & 0 & & 0 & & 0 & \\
\hline Observations & 7,206 & & 7,380 & & 7,563 & \\
\hline
\end{tabular}

Table 5: Logistic Regression 2010 Failures Marginal Effects Estimation.

A number of Call Report variables are significant explanatory factors for 2010 bank failures. Book equity is a consistently significant factor in promoting lower failure likelihoods, net income has this same effect in the first- and third-year gap regressions, and asset reserves have the same negative and significant effect in the first-year gap. The nonperforming assets and construction and land development loan variables have positive and significant marginal effects in all regressions that indicate higher likelihoods of failure. Brokered deposits, multifamily real estate loans and unsecured commercial real estate and land development loans are positive and significant explanatory factors in the second- and third-year gap regressions. 


\begin{tabular}{|c|c|c|c|c|c|c|}
\hline & F 2012- & $2011 Q 4$ & F 2012 - & 2010Q4 & F 2008 & $2009 Q 4$ \\
\hline & $\mathbf{M E} / \mathbf{p}^{1}$ & Mean & ME/p $p^{1}$ & Mean & ME $/ p^{1}$ & Mean \\
\hline rrechg_ma_rer14 & 0.001900 & -0.010278 & -0.102519 & -0.005208 & 0.001900 & -0.010278 \\
\hline & 0.409 & & 0.746 & & 0.409 & \\
\hline rrechg_sa_rer14 & 0.001432 & -0.005672 & -0.087474 & -0.011733 & 0.001432 & -0.005672 \\
\hline & 0.330 & & 0.188 & & 0.330 & \\
\hline rrechg_mt_rer14 & 0.002034 & -0.002527 & 0.140490 & -0.006827 & 0.002034 & -0.002527 \\
\hline & 0.559 & & 0.332 & & 0.559 & \\
\hline rrechg_pac_rer14 & 0.002900 & -0.006027 & 0.822194 & -0.007058 & 0.002900 & -0.006027 \\
\hline & 0.400 & & $0.008 * * *$ & & 0.400 & \\
\hline rrechg_ne_rer14 & 0.004520 & -0.007583 & - & -0.007732 & 0.004520 & -0.007583 \\
\hline & $0.003 * * *$ & & & & $0.003 * * *$ & \\
\hline rrechg_enc_rer14 & -0.000310 & -0.007917 & -0.064072 & -0.008151 & -0.000310 & -0.007917 \\
\hline & 0.779 & & 0.612 & & 0.779 & \\
\hline rrechg_esc_rer14 & -0.001212 & -0.003098 & -0.125939 & -0.007561 & -0.001212 & -0.003098 \\
\hline & 0.692 & & 0.102 & & 0.692 & \\
\hline rrechg_wsc_rer14 & -0.000759 & 0.000819 & -0.084755 & -0.003375 & -0.000759 & 0.000819 \\
\hline & 0.949 & & 0.626 & & 0.949 & \\
\hline rrechg_wnc_rer14 & 0.004120 & -0.001645 & -0.111183 & -0.005141 & 0.004120 & -0.001645 \\
\hline & 0.147 & & 0.267 & & 0.147 & \\
\hline realgdpchg & -0.000238 & 0.020327 & -0.042340 & 0.026805 & -0.000238 & 0.020327 \\
\hline & 0.488 & & $0.080 *$ & & 0.488 & \\
\hline asset_ge10B & - & 0.012941 & -0.000371 & 0.012863 & - & 0.012941 \\
\hline & & & 0.899 & & & \\
\hline te & -0.003775 & & -0.069889 & & -0.003775 & \\
\hline & $0.000 * * *$ & & $0.000 * * *$ & & $0.000 * * *$ & \\
\hline 1lr & -0.003690 & & -0.098707 & & -0.003690 & \\
\hline & $0.002 * * *$ & & $0.028 * *$ & & $0.002 * *$ & \\
\hline roa & -0.000485 & & -0.044225 & & -0.000485 & \\
\hline & 0.182 & & $0.015 * *$ & & 0.182 & \\
\hline npap_lnlsdebt & 0.001869 & & 0.070039 & & 0.001869 & \\
\hline & $0.000 * * *$ & & $0.000 * * *$ & & $0.000 * * *$ & \\
\hline $\mathrm{sec}$ & -0.000241 & & -0.009591 & & -0.000241 & \\
\hline & $0.024 * *$ & & $0.080 *$ & & $0.024 * *$ & \\
\hline bd & 0.000116 & & 0.004765 & & 0.000116 & \\
\hline & 0.204 & & 0.260 & & 0.204 & \\
\hline cashdue & -0.000082 & & -0.002992 & & -0.000082 & \\
\hline & 0.437 & & 0.632 & & 0.437 & \\
\hline goodwill & 0.001181 & & -0.201596 & & 0.001181 & \\
\hline & 0.603 & & $0.059 *$ & & 0.603 & \\
\hline rer14 & -0.000108 & & 0.001059 & & -0.000108 & \\
\hline & 0.102 & & 0.850 & & 0.102 & \\
\hline remul & -0.000194 & & 0.012264 & & -0.000194 & \\
\hline & 0.410 & & 0.145 & & 0.410 & \\
\hline recon & -0.000035 & & -0.004519 & & -0.000035 & \\
\hline & 0.798 & & 0.615 & & 0.798 & \\
\hline recom & -0.000104 & & 0.006937 & & -0.000104 & \\
\hline & 0.205 & & 0.118 & & 0.205 & \\
\hline ci & -0.000233 & & 0.009059 & & -0.000233 & \\
\hline & $0.087 *$ & & 0.250 & & $0.087 *$ & \\
\hline cons & -0.000617 & & -0.024938 & & -0.000617 & \\
\hline & $0.081 *$ & & 0.175 & & 0.081 & \\
\hline constant ${ }^{2}$ & 3.451664 & & -3.138032 & & 3.451664 & \\
\hline & $0.060 *$ & & $0.005 * * *$ & & $0.060 *$ & \\
\hline Pseudo R ${ }^{2}$ & 0.830 & & 0.459 & & 0.830 & \\
\hline BIC & 496 & & 1066 & & 496 & \\
\hline Chi Squared (df) & $134(24)$ & & $351(24)$ & & $357(24)$ & \\
\hline Model Significance $p$ & 0 & & 0 & & 0 & \\
\hline Bank Failures $^{3}$ & 174 & & 166 & & 174 & \\
\hline OBA Banks & 0 & & 0 & & 0 & \\
\hline Observations & 6,834 & & 6,818 & & 6,834 & \\
\hline
\end{tabular}

Table 6: Logistic Regression 2012 Failures Marginal Effects Estimation. 
The economic transformation from the Great Recession period can be seen in Table 6 that shows the bank failure regressions in 2012. The significant regional HPI change-house loan interactions for this failure year have negative and significant ME-Mean effects - New England region in the one- (2011q4) and three-year (2009q4) gaps, and the Pacific region in the two-year gap (2010q4). The real GDP change has a negative and significant ME-Mean effect in the two-year gap where the mean state-level GDP values are positive in $2010 \mathrm{q} 4$.

The Call Report variables for 2012 bank failure regressions show that the bank book equity, asset loss reserves and securities have negative and significant marginal effects on bank failures in all regressions. The C\&I and Consumer (cons) loans have significant negative effects in the one- and threeyear gaps, while net income and intangible assets have significant negative effects in the two-year gap. Nonperforming assets is the only bank-reported variable that has significant and positive effects on the likelihood of failure for all regressions. Note that the loans for construction and land development that are secured by real estate are not significant in any regression. This is the first failure period since the Great Recession period of 2008 where these commercial real estate loans secured by real estate are not significant for the majority of the posted regressions in any prior failure year (Table A.1 shows the 2011 failure year which does have a positive and significant effect for recon for the 2- and 3year gaps).

\begin{tabular}{|c|c|c|c|c|c|c|}
\hline \multirow{4}{*}{ rrechg_ma_rer14 } & \multicolumn{2}{|c|}{ F 2014 - IV 2013Q4 } & \multicolumn{2}{|c|}{ F 2014 - IV 2012 Q4 } & \multicolumn{2}{|c|}{ F 2014 - IV 2011Q4 } \\
\hline & $\mathbf{M E} / \mathbf{p}^{1}$ & Mean & ME/p ${ }^{1}$ & Mean & $\mathbf{M E} / \mathbf{p}^{1}$ & Mean \\
\hline & 0.000064 & 0.008335 & 0.049852 & 0.003895 & 0.044135 & -0.010278 \\
\hline & 0.947 & & 0.139 & & 0.773 & \\
\hline \multirow[t]{2}{*}{ rrechg_sa_rer14 } & -0.000195 & 0.014752 & -0.003169 & 0.011271 & -0.284202 & -0.005672 \\
\hline & 0.426 & & 0.736 & & $0.079 *$ & \\
\hline \multirow[t]{2}{*}{ rrechg_mt_rer14 } & -0.000773 & 0.008817 & -0.020808 & 0.010865 & -0.280770 & -0.002527 \\
\hline & 0.457 & & 0.345 & & 0.114 & \\
\hline \multirow[t]{2}{*}{ rrechg_pac_rer14 } & 0.000362 & 0.016371 & 0.011655 & 0.011496 & -0.178141 & -0.006027 \\
\hline & $0.023 * *$ & & $0.049 * *$ & & $0.072 *$ & \\
\hline \multirow[t]{2}{*}{ rrechg_ne_rer14 } & - & 0.013200 & -0.018218 & 0.003087 & 0.171153 & -0.007583 \\
\hline & & & $0.011 * *$ & & $0.000 * * *$ & \\
\hline \multirow{2}{*}{ rrechg_enc_rer14 } & -0.000188 & 0.011903 & 0.000817 & 0.004606 & -0.114442 & -0.007917 \\
\hline & 0.757 & & 0.938 & & 0.228 & \\
\hline \multirow[t]{2}{*}{ rrechg_esc_rer14 } & -0.001331 & 0.007295 & -0.064305 & 0.006099 & 0.127110 & -0.003098 \\
\hline & 0.275 & & $0.049 * *$ & & 0.522 & \\
\hline \multirow[t]{2}{*}{ rrechg_wsc_rer14 } & -0.004748 & 0.007033 & -0.155032 & 0.006070 & -0.301846 & 0.000819 \\
\hline & 0.127 & & $0.008 * * *$ & & 0.466 & \\
\hline \multirow[t]{2}{*}{ rrechg_wnc_rer14 } & -0.000073 & 0.005473 & -0.023733 & 0.005179 & 0.072561 & -0.001645 \\
\hline & 0.870 & & 0.468 & & 0.774 & \\
\hline \multirow[t]{2}{*}{ realgdpchg } & 0.000234 & 0.026047 & 0.000244 & 0.000224 & -0.006525 & 0.020327 \\
\hline & 0.166 & & 0.875 & & 0.590 & \\
\hline asset_ge10B & - & 0.014365 & - & 0.013562 & - & 0.012941 \\
\hline \multirow[t]{2}{*}{ te } & -0.000668 & & -0.016529 & & -0.065185 & \\
\hline & $0.000 * * *$ & & $0.000 * * *$ & & $0.000 * * *$ & \\
\hline \multirow[t]{2}{*}{$11 \mathrm{r}$} & -0.000087 & & -0.008738 & & -0.066401 & \\
\hline & 0.650 & & 0.278 & & 0.161 & \\
\hline \multirow[t]{2}{*}{ roa } & -0.000013 & & -0.001852 & & 0.000421 & \\
\hline & $0.003 * * *$ & & $0.000 * * *$ & & 0.984 & \\
\hline \multirow{2}{*}{ npap_lnlsdebt } & 0.000262 & & 0.006780 & & 0.021753 & \\
\hline & $0.000 * * *$ & & $0.000 * * *$ & & $0.000 * * *$ & \\
\hline \multirow[t]{2}{*}{$\sec$} & -0.000053 & & 0.000010 & & -0.002548 & \\
\hline & $0.000 * * *$ & & 0.987 & & 0.415 & \\
\hline \multirow[t]{2}{*}{$\mathrm{bd}$} & 0.000011 & & 0.000643 & & -0.001325 & \\
\hline & 0.760 & & 0.437 & & 0.831 & \\
\hline \multirow[t]{2}{*}{ cashdue } & -0.000073 & & -0.001014 & & -0.008282 & \\
\hline & $0.005 * * *$ & & 0.274 & & $0.065 *$ & \\
\hline \multirow[t]{2}{*}{ goodwill } & -0.000968 & & -0.094370 & & -0.118914 & \\
\hline & 0.495 & & $0.090 *$ & & 0.306 & \\
\hline rer14 & -0.000044 & & -0.000682 & & -0.006934 & \\
\hline & $0.075 *$ & & 0.319 & & 0.218 & \\
\hline remul & -0.000019 & & -0.000290 & & 0.004749 & \\
\hline & 0.484 & & 0.847 & & 0.390 & \\
\hline recon & -0.000033 & & 0.002033 & & 0.008401 & \\
\hline & 0.390 & & $0.075 *$ & & 0.163 & \\
\hline recom & -0.000050 & & -0.000582 & & 0.001870 & \\
\hline & $0.000 * * *$ & & 0.351 & & 0.547 & \\
\hline
\end{tabular}




\begin{tabular}{|c|c|c|c|c|}
\hline \multirow[t]{2}{*}{ ci } & -0.000044 & 0.000215 & -0.004426 & \\
\hline & 0.172 & 0.853 & 0.517 & \\
\hline \multirow[t]{2}{*}{ cons } & -0.000030 & 0.000946 & 0.005100 & \\
\hline & 0.169 & 0.380 & 0.379 & \\
\hline \multirow{2}{*}{ constant $^{2}$} & 5.761592 & -0.281888 & -1.021429 & \\
\hline & $0.002 * * *$ & 0.859 & 0.437 & \\
\hline Pseudo R ${ }^{2}$ & 0.813 & 0.561 & 0.386 & \\
\hline $\mathrm{BIC}$ & 368 & 590 & 734 & \\
\hline Chi Squared (df) & $239(23)$ & $236(24)$ & $288(24)$ & \\
\hline Model Significance $p$ & 0 & 0 & 0 & \\
\hline Bank Failures $^{3}$ & 78 & 77 & 76 & \\
\hline OBA Banks & 0 & 0 & 0 & \\
\hline Observations & 6,333 & 6,728 & 6,834 & \\
\hline
\end{tabular}

Table 7: Logistic Regression 2014 Failures Marginal Effects Estimation.

Table 7 contains the bank failure marginal effect estimates for 2014 failures and continue to see effects by many different explanatory variables. Recall there were only 18 bank failures in 2014 (Figure 6). The Pacific regional HPI change interaction has ME-Mean effects that positively and significantly explain higher likelihoods of bank failures in all regressions. The South Atlantic regional HPI change-house loan interaction has a ME-Mean effect that positively and significantly explains bank failures in the three-year (2011q4) gap regression. The New England regional change interaction variable has significant and negative ME-Mean effects in the two- (2012q4) and three-year (2011q4) regressions. The West South Central regional change interaction variable's ME-Mean effects are negative, significant and slightly above the $10 \%$ significance in the two- and one-year (2013q4) gaps, respectively. The East South Central regional change interaction ME-Mean effect is negative and significant in twoyear gap regression.

The Call Report variables that significantly explain bank failures in 2014 in all regressions are book equity that has negative effects on likelihoods of failure and non-performing assets that has positive effects. The net income effects have negative and significant effects in the one- and two-year gaps. There are multiple variable effects that occur in single year gaps. Secured loans for construction and land development has a slightly significant and positive marginal effect in the twoyear gap. For significant and negative effects on bank failures, there are securities, cash from banks, 1 to 4 Family loans and non-secured construction finance loans in the one-year gap regression while the intangible assets variable is in the twoyear gap.

These regression results show that the bank failures during and after the Great Recession period differ from recession to recovery. We see that financial distress occurred to larger banks that are shown by the consistently significant estimated dummy variable values of at least $\$ 10$ billion banks during the 2008 and 2009 failure years. The ME-Mean results also show that different regions of residential real estate HPI changehouse loan interactions had consistently significant effects that explain bank failures by either increasing or decreasing the failure likelihoods over 2008 through 2015 periods. These significant marginal effects that explain bank failures demonstrate the impacts of regional residential house price changes on these house loans on bank balance sheets are meaningful in determining effects on bank failures over this collective period. Some Call Report variables contain marginal effects that significantly explain bank failures, such as nonperforming loans, securities and book equity over the entire regression period. Asset loss reserves and brokered deposits have significant explanatory power over 2008-2012, while secured commercial real estate loans for construction and land development and multifamily real estate loans were significant for 2008-2011 period.

The estimated marginal effects for the regional residential HPI change-house loan interaction variables vary greatly for the different estimation periods due to the dynamic movements in these HPI values. Depending on the period in which the residential house price changes are measured, the regional HPI change-house loan interaction variables show very different effects for their relationship to bank failures. As we observe in Figure 4, these regional residential real estate markets provide unstable movements in their relative HPI changes and their changing conditions does have an effect on the accuracy of the out-of-sample tests that we show below.

\subsection{Regression Fit and Forecast Tests}

In this sub-section, we compare the fits and forecasts of the regression models that use the regional residential HPI change-house loan interactions and the traditional bankreported Call Report variables (HPI-CR) and the bankreported variables (CR). As Table 8 shows, the HPI-CR model significantly improves the bank failure estimation fits using the likelihood ratio tests. More specifically, the improvements in fit are statistically significant for 20 of the 241 - to 3-year gap regressions for the Failure Years from 2008 through 2015. 


\begin{tabular}{|c|c|c|c|c|c|c|}
\hline \multicolumn{7}{|c|}{ Model Comparison: Regional Annual HPI Change \& Call Report vs. Call Report } \\
\hline Failure Year & Regressor Lag & Regressor Date & Degrees of & Chi Squared & \multicolumn{2}{|c|}{ P Value } \\
\hline 2008 & 1-Year & $2007 q 4$ & 11 & 27.803 & 0.003 & $* * *$ \\
\hline 2008 & 2-Year & $2006 \mathrm{q} 4$ & 11 & 23.482 & 0.015 & $* *$ \\
\hline 2008 & 3-Year & $2005 q 4$ & 11 & 32.222 & 0.001 & $* * *$ \\
\hline 2009 & 1-Year & $2008 \mathrm{q} 4$ & 11 & 33.674 & 0.000 & **** \\
\hline 2009 & 2-Year & $2007 q 4$ & 11 & 66.292 & 0.000 & $* * *$ \\
\hline 2009 & 3-Year & $2006 q 4$ & 11 & 61.268 & 0.000 & $* * *$ \\
\hline 2010 & 1-Year & $2009 q 4$ & 11 & 18.079 & 0.080 & $*$ \\
\hline 2010 & 2-Year & $2008 \mathrm{q} 4$ & 11 & 53.073 & 0.000 & $* * *$ \\
\hline 2010 & 3-Year & $2007 q 4$ & 11 & 53.894 & 0.000 & $* * *$ \\
\hline 2011 & 1-Year & $2010 q 4$ & 10 & 21.424 & 0.018 & $* *$ \\
\hline 2011 & 2-Year & $2009 q 4$ & 10 & 25.481 & 0.005 & $* * *$ \\
\hline 2011 & 3-Year & $2008 \mathrm{q} 4$ & 10 & 43.012 & 0.000 & $* * *$ \\
\hline 2012 & 1-Year & $2011 q 4$ & 10 & 3.067 & 0.980 & \\
\hline 2012 & 2-Year & $2010 q 4$ & 10 & 23.735 & 0.008 & $* * *$ \\
\hline 2012 & 3-Year & $2009 q 4$ & 10 & 23.109 & 0.010 & $* *$ \\
\hline 2013 & 1-Year & $2012 q 4$ & 10 & 16.332 & 0.091 & $*$ \\
\hline 2013 & 2-Year & $2011 q 4$ & 10 & 9.469 & 0.488 & \\
\hline 2013 & 3-Year & $2010 q 4$ & 11 & 14.833 & 0.190 & \\
\hline 2014 & 1-Year & $2013 q 4$ & 9 & 14.689 & 0.100 & $*$ \\
\hline 2014 & 2-Year & $2012 q 4$ & 10 & 19.056 & 0.040 & $* *$ \\
\hline 2014 & 3-Year & $2011 q 4$ & 10 & 16.075 & 0.098 & $*$ \\
\hline 2015 & 1-Year & $2014 q 4$ & 10 & 17.691 & 0.060 & $*$ \\
\hline 2015 & 2-Year & $2013 q 4$ & 9 & 11.146 & 0.266 & \\
\hline 2015 & 3-Year & $2012 q 4$ & 10 & 18.022 & 0.055 & $*$ \\
\hline
\end{tabular}

Table 8: Likelihood Ratio Test - Model Comparison.

The In-Sample and Out-of-Sample receiver operating characteristic (ROC) curve comparisons between these two models are shown in Figures 7 and 8, respectively, where the area under the curve (AUC) comparisons utilize an algorithm suggested by DeLong, et al. [12]. These ROC comparisons test the models' relative abilities to accurately forecast bank failures. We compare each AUC and plot the HPI-CR and CR differences in the vertical bar graphs. These In-Sample ROC comparisons match the Likelihood Ratio test results. They demonstrate that the HPI-CR model has better regression fits overall and they have significantly superior fits, especially early in the bank failure sample of 2008 through 2011. The Out-of-Sample ROC comparisons show that the CR model has significantly better prediction forecasts for most regression settings. The difference in these In-Sample and Out-of-Sample results is due to the unstable residential housing market over the sample period providing the major difference between these two models. The Purchase Only, FHFA regional Residential HPI values during the 2005-2016 period has a volatility (standard deviation) that is larger than that over the prior 1992-2004 period. With the HPI-CR model having mostly significantly better In-Sample results and the CR model having mostly significantly better Out-of-Sample forecasts, this is not an example of model overfitting. Rather, it is interesting that this demonstrates that the volatile movements of the variables that include the regional HPI change values over the sample period that surrounds the Great
Recession may explain the dramatically different out-ofsample results for the model comparisons.

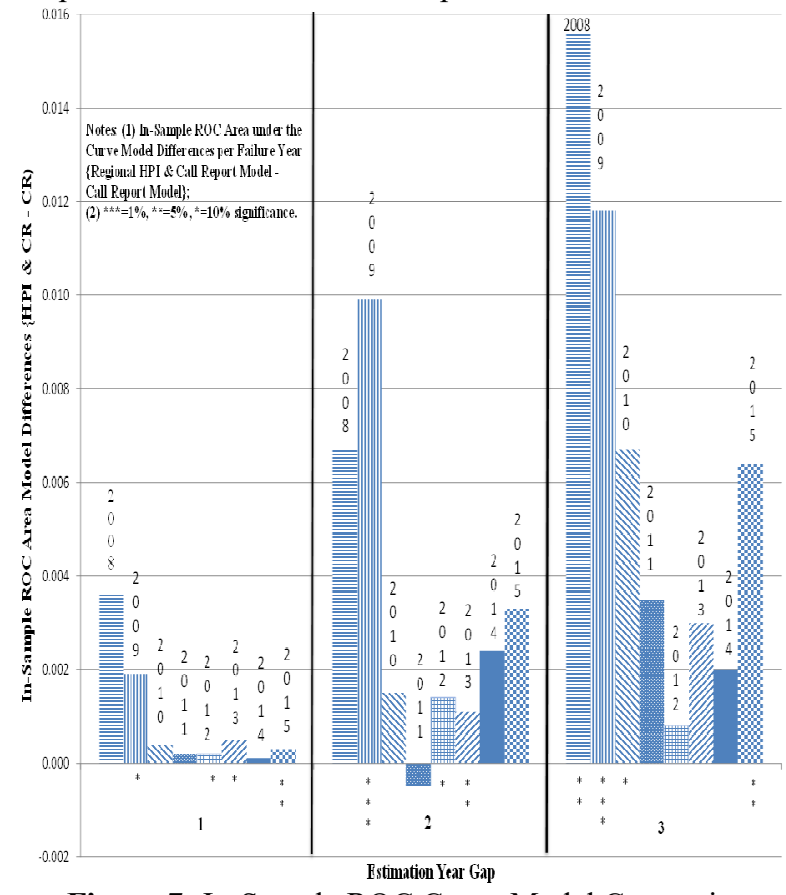

Figure 7: In-Sample ROC Curve Model Comparison. 

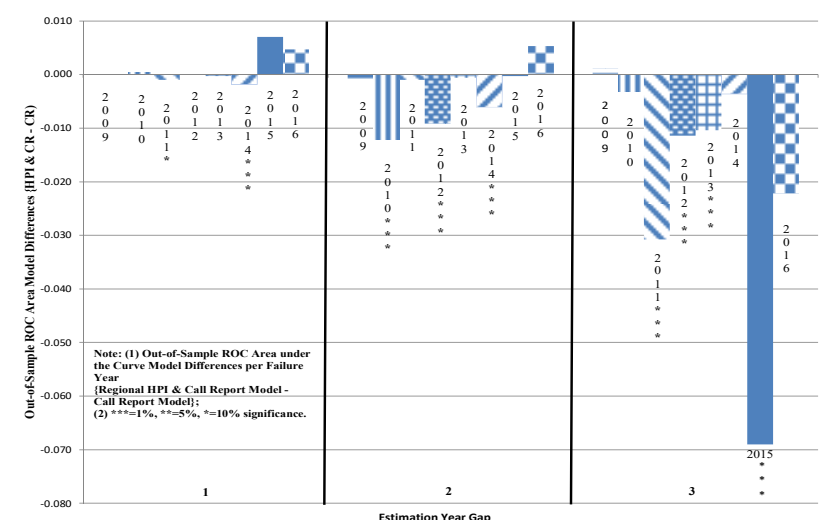

Estimation Year Gap

Figure 8: Out-of-Sample ROC Curve Model Comparison.

Tables 9, 10 and 11 present out-of-sample tests of the Actual failures and Tables 12, 13 and 14 are for the combination of Actual and Technical (Actual-Technical) failure tabulations for 2010 based on 2009 bank failure model estimations. These out-of-sample tabulations are forecasts of the estimated regressions that are one year ahead of the estimation period. So if there is a regression of 2009 failures on 2006q4 independent variables, then the out-of-sample tabulation would be the 2010 failure projections using 2007q4 independent variables. These tables validate the logistic regression's forecast abilities but identify the hazards of using the regional residential HPI change interactions during periods of instability in real estate markets. These out-of-sample data show that these regressions produce very accurate forecasts for the one-, two- and three-year forecasts out-of-sample tests for 2009 bank failures, given that the uninformed level is $50 \%$. The one- and two-year correct bank failure forecasts are above $90 \%$ for both the actual and actual-technical failures. The oneyear correct failure predictions are 98 and $94 \%$ for these two failure groups, the two-year correct failure predictions are 94 and $95 \%$, while the three-year correct forecasts are 79 and 83 $\%$ for these failure groups.

\begin{tabular}{|c|c|c|c|}
\hline \multirow{2}{*}{$\begin{array}{c}\text { Predicted } \\
\text { Actual } \\
\text { Failures }\end{array}$} & \multicolumn{2}{|c|}{ Actual Failures } & \multirow{2}{*}{ Total } \\
\cline { 2 - 3 } & No Fail (0) & Fail (1) & \\
\hline $\mathbf{0}$ & 6,562 & 3 & 6,565 \\
& 92.828 & 2.190 & 91.105 \\
\hline $\mathbf{1}$ & 507 & 134 & 641 \\
& 7.172 & 97.810 & 8.895 \\
\hline Total & 7,069 & 137 & 7,206 \\
& 100 & 100 & 100 \\
\hline
\end{tabular}

Notes: Bottom cell level - column \%age; Failure Cutoff: 0.05; Prediction Date: DV - 2010 Failures using IV - 2009q4.

Table 9: Out-of-Sample Tabulation -- Actual Failures vs Predicted Failures (One - Year Look-Ahead, One - Year Prediction Date: DV - 2010 Bank Failures using IV - 2009q4 Data).

\begin{tabular}{|c|c|c|c|}
\hline \multirow{2}{*}{$\begin{array}{c}\text { Predicted } \\
\text { Actual } \\
\text { Failures }\end{array}$} & \multicolumn{2}{|c|}{ Actual Failures } & \multirow{2}{*}{ Total } \\
\cline { 2 - 3 } & No Fail (0) & Fail (1) & \\
\hline \multirow{0}{*}{$\mathbf{1}$} & 5,115 & 8 & 5,123 \\
& 70.561 & 6.107 & 69.417 \\
\hline \multirow{2}{*}{ Total } & 2,134 & 123 & 2,257 \\
& 29.439 & 93.893 & 30.583 \\
& 7,249 & 131 & 7,380 \\
& 100 & 100 & 100 \\
\hline
\end{tabular}

Notes: Bottom cell level - column \%age; Failure Cutoff: 0.05; Prediction Date: DV - 2010 Failures using IV - 2008q4.

Table 10: Out-of-Sample Tabulation -- Actual Failures vs Predicted Failures (Two - Year Look-Ahead, Two - Year Prediction Date: DV - 2010 Bank Failures using IV - 2008q4 Data).

\begin{tabular}{|c|c|c|c|}
\hline \multirow{2}{*}{$\begin{array}{c}\text { Predicted } \\
\text { Actual } \\
\text { Failures }\end{array}$} & \multicolumn{2}{|c|}{ Actual Failures } & \multirow{2}{*}{ Total } \\
\cline { 2 - 3 } & No Fail (0) & Fail (1) & \\
\hline $\mathbf{0}$ & 5,883 & 27 & 5,910 \\
& 79.115 & 21.260 & 78.144 \\
\hline $\mathbf{1}$ & 1,553 & 100 & 1,653 \\
& 20.885 & 78.740 & 21.856 \\
\hline \multirow{2}{*}{ Total } & 7,436 & 127 & 7,563 \\
& 100 & 100 & 100 \\
\hline
\end{tabular}

Notes: Bottom cell level - column \%age; Failure Cutoff: 0.05; Prediction Date: DV - 2010 Failures using IV - 2007q4.

Table 11: Out-of-Sample Tabulation - Actual Failures vs Predicted Failures (Three - Year Look-Ahead, Three - Year Prediction Date: DV - 2010 Bank Failures using IV - 2007q4 Data).

\begin{tabular}{|c|c|c|c|}
\hline \multirow{2}{*}{$\begin{array}{c}\text { Predicted } \\
\text { Act-Tech } \\
\text { Failures }\end{array}$} & \multicolumn{2}{|c|}{ Act-Tech Failures } & \multirow{2}{*}{ Total } \\
\cline { 2 - 3 } & No Fail (0) & Fail (1) & \\
\hline $\mathbf{0}$ & 6,547 & 18 & 6,565 \\
& 94.967 & 5.769 & 91.105 \\
\hline $\mathbf{1}$ & 347 & 294 & 641 \\
& 5.033 & 94.231 & 8.895 \\
\hline \multirow{2}{*}{ Total } & 6,894 & 312 & 7,206 \\
& 100 & 100 & 100 \\
\hline
\end{tabular}

Notes: Bottom cell level - column \%age; Failure Cutoff: 0.05; Prediction Date: DV - 2010 Failures using IV - 2009q4.

Table 12: Out-of-Sample Tabulation - Actual-Technical Failures vs Predicted Failures (One - Year Look-Ahead, One Year Prediction Date: DV - 2010 Bank Failures using IV 2009q4 Data). 


\begin{tabular}{|c|c|c|c|}
\hline \multirow{2}{*}{$\begin{array}{c}\text { Predicted } \\
\text { Act-Tech } \\
\text { Failures }\end{array}$} & \multicolumn{2}{|c|}{ Act-Tech Failures } & \multirow{2}{*}{ Total } \\
\cline { 2 - 3 } & No Fail (0) & Fail (1) & \\
\hline $\mathbf{0}$ & 5,107 & 16 & 5,123 \\
& 72.123 & 5.351 & 29.417 \\
\hline $\mathbf{1}$ & 1,974 & 283 & 2,257 \\
& 27.877 & 94.649 & 30.583 \\
\hline Total & 7,081 & 299 & 7,380 \\
& 100 & 100 & 100 \\
\hline
\end{tabular}

Notes: Bottom cell level - column \%age; Failure Cutoff: 0.05;

Prediction Date: DV - 2010 Failures using IV - 2008q4.

Table 13: Out-of-Sample Tabulation - Actual-Technical

Failures vs Predicted Failures (Two - Year Look-Ahead, Two

- Year Prediction Date: DV - 2010 Bank Failures using IV 2008q4 Data).

\begin{tabular}{|c|c|c|c|}
\hline $\begin{array}{c}\text { Predicted } \\
\text { Act-Tech } \\
\text { Failures }\end{array}$ & \multicolumn{2}{|c|}{ Act-Tech Failures } & \multirow{2}{*}{ Total } \\
\cline { 2 - 3 } & No Fail (0) & Fail (1) & \\
\hline $\mathbf{0}$ & 5,862 & 48 & 5,910 \\
& 80.555 & 16.783 & 78.144 \\
\hline $\mathbf{1}$ & 1,415 & 238 & 1,653 \\
& 19.445 & 83.217 & 21.856 \\
\hline Total & 7,277 & 286 & 7,563 \\
& 100 & 100 & 100 \\
\hline
\end{tabular}

Notes: Bottom cell level - column \%age; Failure Cutoff: 0.05; Prediction Date: DV - 2010 Failures using IV - 2007q4.

Table 14: Out-of-Sample Tabulation - Actual-Technical Failures vs Predicted Failures (Three - Year Look-Ahead, Three - Year Prediction Date: DV - 2010 Bank Failures using IV - 2007q4 Data).

\section{SUMMARY AND CONCLUSIONS}

The recent financial crisis and the Great recession of 20072009 had several root causes, and we show that regional residential annual HPI changes interacting with bank

\begin{tabular}{|c|c|c|c|c|c|c|}
\hline & \multicolumn{2}{|c|}{ F 2011 - IV 2010Q4 } & \multicolumn{2}{|c|}{ F 2011 - IV 2009Q4 } & \multicolumn{2}{|c|}{ F 2011 - IV 2008Q4 } \\
\hline & $\mathrm{ME} / \mathrm{p}^{1}$ & Mean & $\mathrm{ME} / \mathbf{p}^{1}$ & Mean & $\mathbf{M E} / \mathbf{p}^{1}$ & Mean \\
\hline \multirow[t]{2}{*}{ rrechg_ma_rer14 } & -0.001966 & -0.005208 & 0.245847 & -0.005424 & 0.127385 & -0.016458 \\
\hline & 0.749 & & 0.681 & & 0.572 & \\
\hline \multirow[t]{2}{*}{ rrechg_sa_rer14 } & -0.001129 & -0.011733 & -0.277113 & -0.008654 & -0.024652 & -0.030829 \\
\hline & 0.567 & & $0.015 * *$ & & 0.570 & \\
\hline \multirow[t]{2}{*}{ rrechg_mt_rer14 } & 0.002836 & -0.006827 & 0.859714 & -0.003433 & 0.306430 & -0.011211 \\
\hline & 0.316 & & $0.095 *$ & & $0.092 *$ & \\
\hline \multirow[t]{2}{*}{ rrechg_pac_rer14 } & 0.011172 & -0.007058 & 0.799325 & -0.005239 & 0.164824 & -0.022864 \\
\hline & 0.111 & & 0.204 & & 0.336 & \\
\hline rrechg_ne_rer14 & - & -0.007732 & - & -0.006886 & 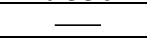 & -0.025259 \\
\hline \multirow[t]{2}{*}{ rrechg_enc_rer14 } & 0.002265 & -0.008151 & -0.172645 & -0.006628 & 0.136277 & -0.018598 \\
\hline & 0.419 & & 0.419 & & 0.244 & \\
\hline \multirow[t]{2}{*}{ rrechg_esc_rer14 } & -0.001105 & -0.007561 & -0.572963 & -0.002433 & 0.049864 & -0.008601 \\
\hline & 0.569 & & $0.067 *$ & & 0.858 & \\
\hline
\end{tabular}

residential mortgage loans significantly explain bank failure during and beyond this period inclusive of years 2008 to 2015. Much of the existing literature focuses on subprime mortgages as a root cause. This paper finds that the regional HPI change effects on residential real estate lending are important explanations of bank financial health. We also find that commercial real estate lending is a major contributing factor explaining bank failures during the earlier part of this period including 2008 to 2011. We show that regional residential house price movement interactions with banks' residential mortgage loans have been significant explanatory factors through 2015 showing the ability to both raise and lower the likelihoods of failure. It is important to know that these direct effects of residential house price changes on bank residential house loans have important effects on banks financial health. Our results are supported by robust testing beyond our regression analysis.

An aspect that is unique for bank failures during the period of the Great Recession is that many larger banks failed compared to previous downturns. We see that for the 2008 and 2009 failures the estimated logistic model coefficient for the large bank (assets at least $\$ 10$ billion) dummy variable is positive and significant. The positive sign indicates that larger banks in these periods have a greater likelihood of failure. We note that the typical bank failure models show that smaller banks have a higher likelihood of failure. All of these factors demonstrate that the recent financial crisis had some unique financial causes and effects that we have attempted to identify, particularly the effect of regional HPI changes working through various aspects of bank real estate lending to effect bank failure.

\section{ACKNOWLEDGEMENT}

The views in this paper are those of the authors and do not reflect the views of the FDIC Board or its Staff. Please do not quote without permission from the authors. We appreciate the insightful discussions of this paper with Jonathan Pogach, Jeff Traczynski, Allen Berger and comments from the AEAAREUEA and ARES conferences.

\section{APPENDIX}

\section{Appendix A:}




\begin{tabular}{|c|c|c|c|c|c|c|}
\hline \multirow[t]{2}{*}{ rrechg_wsc_rer14 } & -0.002333 & -0.003375 & 0.068630 & 0.001565 & 0.348070 & -0.003712 \\
\hline & 0.393 & & 0.920 & & 0.454 & \\
\hline \multirow{2}{*}{ rrechg_wnc_rer14 } & -0.002283 & -0.005141 & -1.177187 & -0.000915 & -0.164904 & -0.006503 \\
\hline & 0.393 & & $0.037 * *$ & & 0.258 & \\
\hline \multirow[t]{2}{*}{ realgdpchg } & -0.001504 & 0.026805 & -0.001101 & -0.001101 & -0.123167 & -0.023263 \\
\hline & $0.028 * *$ & & 0.975 & & $0.000 * * *$ & \\
\hline \multirow[t]{2}{*}{ asset_ge10B } & 0.000132 & 0.012863 & -0.004739 & 0.012569 & -0.001248 & 0.013137 \\
\hline & $0.084 *$ & & 0.409 & & 0.878 & \\
\hline \multirow[t]{2}{*}{ te } & -0.007146 & & -0.120349 & & -0.105499 & \\
\hline & $0.000 * * *$ & & $0.000 * * *$ & & $0.000 * * *$ & \\
\hline \multirow[t]{2}{*}{$11 \mathrm{r}$} & -0.003721 & & -0.201520 & & -0.549875 & \\
\hline & $0.000 * * *$ & & $0.053 *$ & & $0.000 * * *$ & \\
\hline \multirow[t]{2}{*}{ roa } & -0.000141 & & -0.027599 & & 0.027884 & \\
\hline & 0.815 & & 0.498 & & $0.000 * * *$ & \\
\hline \multirow[t]{2}{*}{ npap_lnlsdebt } & 0.003123 & & 0.124609 & & 0.102259 & \\
\hline & $0.000 * * *$ & & $0.000 * * *$ & & $0.000 * * *$ & \\
\hline \multirow[t]{2}{*}{ sec } & -0.000018 & & -0.001517 & & 0.000680 & \\
\hline & 0.930 & & 0.900 & & 0.957 & \\
\hline \multirow[t]{2}{*}{ bd } & 0.000239 & & 0.015635 & & 0.001400 & \\
\hline & $0.049 * *$ & & $0.054 *$ & & 0.821 & \\
\hline \multirow{2}{*}{ cashdue } & -0.000235 & & 0.007493 & & -0.024514 & \\
\hline & 0.302 & & 0.602 & & 0.239 & \\
\hline \multirow[t]{2}{*}{ goodwill } & 0.005669 & & -0.116496 & & 0.017325 & \\
\hline & $0.002 * * *$ & & 0.351 & & 0.839 & \\
\hline \multirow{2}{*}{ rer14 } & 0.000107 & & 0.011642 & & 0.022854 & \\
\hline & 0.577 & & 0.262 & & $0.049 * *$ & \\
\hline \multirow[t]{2}{*}{ remul } & 0.000304 & & 0.018823 & & 0.035528 & \\
\hline & 0.392 & & 0.403 & & $0.026 * *$ & \\
\hline \multirow[t]{2}{*}{ recon } & 0.000304 & & 0.057969 & & 0.070937 & \\
\hline & 0.257 & & $0.000 * * *$ & & $0.000 * * *$ & \\
\hline \multirow{2}{*}{ recom } & 0.000160 & & 0.042066 & & 0.053167 & \\
\hline & 0.377 & & $0.000 * * *$ & & $0.000 * * *$ & \\
\hline \multirow[t]{2}{*}{ ci } & 0.000453 & & 0.031687 & & 0.035799 & \\
\hline & 0.104 & & $0.024 * *$ & & $0.002 * * *$ & \\
\hline \multirow[t]{2}{*}{ cons } & 0.000198 & & -0.010272 & & -0.003761 & \\
\hline & 0.611 & & 0.726 & & 0.886 & \\
\hline \multirow{2}{*}{ constant $^{2}$} & -0.311888 & & -5.370294 & & -5.798916 & \\
\hline & 0.897 & & $0.000 * * *$ & & $0.000 * * *$ & \\
\hline$\overline{\text { Pseudo R }}{ }^{2}$ & 0.821 & & 0.343 & & 0.262 & \\
\hline BIC & 601 & & 1532 & & 1656 & \\
\hline Chi Squared (df) & $379(24)$ & & $391(24)$ & & $391(24)$ & \\
\hline Model Significance $p$ & 0 & & 0 & & 0 & \\
\hline Bank Failures $^{3}$ & 247 & & 226 & & 217 & \\
\hline OBA Banks & 0 & & 0 & & 0 & \\
\hline Observations & 6,818 & & 6,979 & & 7,143 & \\
\hline $\begin{array}{l}\text { All } \mathrm{p} \text { values are basec } \\
* * *=1 \% ; * *=5 \% ; \\
* * *=1 \% \cdot * *=5 \%\end{array}$ & tic regressio & & & & ically Fail & \\
\hline
\end{tabular}

Table A1: Logistic Regression 2011 Failures Marginal Effects Estimation.

\begin{tabular}{|c|c|c|c|c|c|c|}
\hline & \multicolumn{2}{|c|}{ F 2013 - IV 2012Q4 } & \multicolumn{2}{|c|}{ F 2013 - IV 2011Q4 } & \multicolumn{2}{|c|}{ F 2013 - IV 2010Q4 } \\
\hline & $\mathbf{M E} / \mathbf{p}^{1}$ & Mean & $\mathbf{M E} / \mathbf{p}^{1}$ & Mean & $\mathbf{M E} / \mathbf{p}^{1}$ & Mean \\
\hline \multirow[t]{2}{*}{ rrechg_ma_rer14 } & 0.004931 & 0.003895 & 0.145339 & -0.010278 & 0.334073 & -0.005208 \\
\hline & 0.141 & & 0.165 & & 0.331 & \\
\hline \multirow[t]{2}{*}{ rrechg_sa_rer14 } & 0.000853 & 0.011271 & -0.011827 & -0.005672 & -0.067288 & -0.011733 \\
\hline & $0.098 *$ & & 0.916 & & 0.209 & \\
\hline \multirow{2}{*}{ rrechg_mt_rer14 } & -0.000290 & 0.010865 & 0.024091 & -0.002527 & 0.043221 & -0.006827 \\
\hline & 0.586 & & 0.830 & & 0.697 & \\
\hline \multirow[t]{2}{*}{ rrechg_pac_rer14 } & 0.000306 & 0.011496 & -0.046349 & -0.006027 & 0.062376 & -0.007058 \\
\hline & 0.506 & & 0652 & & 0.752 & \\
\hline \multirow[t]{2}{*}{ rrechg_ne_rer14 } & -0.002220 & 0.003087 & 0.080447 & -0.007583 & 0.440731 & -0.007732 \\
\hline & 0.567 & & 0.166 & & 0.250 & \\
\hline \multirow[t]{2}{*}{ rrechg_enc_rer14 } & -0.003497 & 0.004606 & 0.005005 & -0.007917 & -0.039559 & -0.008151 \\
\hline & 0.137 & & 0.917 & & 0.689 & \\
\hline rrechg esc rer14 & -0.000720 & 0.006099 & -0.045775 & -0.003098 & -0.066917 & -0.007561 \\
\hline
\end{tabular}




\begin{tabular}{|c|c|c|c|c|c|c|}
\hline & 0.754 & & 0.690 & & 0.310 & \\
\hline \multirow[t]{2}{*}{ rrechg_wsc_rer14 } & -0.002488 & 0.006070 & 0.165082 & 0.000819 & -0.107142 & -0.003375 \\
\hline & 0.201 & & 0.313 & & 0.356 & \\
\hline \multirow[t]{2}{*}{ rrechg_wnc_rer14 } & -0.003005 & 0.005179 & 0.332146 & -0.001645 & 0.150143 & -0.005141 \\
\hline & $0.085 *$ & & $0.000 * * *$ & & 0.353 & \\
\hline \multirow[t]{2}{*}{ realgdpchg } & -0.000184 & 0.004195 & -0.007876 & 0.020327 & -0.050929 & 0.026805 \\
\hline & 0.329 & & 0.472 & & $0.014 * *$ & \\
\hline \multirow[t]{2}{*}{ asset_ge10B } & - & 0.013562 & - & 0.012941 & 0.000167 & 0.012863 \\
\hline & & & & & 0.940 & \\
\hline \multirow[t]{2}{*}{ te } & -0.001430 & & -0.051566 & & -0.035146 & \\
\hline & $0.096 *$ & & $0.000 * * *$ & & $0.001 * * *$ & \\
\hline \multirow[t]{2}{*}{$11 \mathrm{r}$} & -0.000566 & & -0.050889 & & -0.068349 & \\
\hline & 0.607 & & 0.115 & & $0.035^{* *}$ & \\
\hline \multirow[t]{2}{*}{ roa } & -0.000167 & & 0.000335 & & 0.006576 & \\
\hline & $0.072 *$ & & 0.982 & & 0.634 & \\
\hline \multirow[t]{2}{*}{ npap_lnlsdebt } & 0.000975 & & 0.035608 & & 0.047101 & \\
\hline & $0.001 * * *$ & & $0.000 * * *$ & & $0.000 * * *$ & \\
\hline \multirow[t]{2}{*}{$\mathrm{sec}$} & 0.000100 & & 0.000846 & & 0.001513 & \\
\hline & 0.276 & & 0.806 & & 0.742 & \\
\hline \multirow[t]{2}{*}{$\mathrm{bd}$} & 0.000022 & & 0.003789 & & 0.004999 & \\
\hline & 0.735 & & 0.277 & & 0.124 & \\
\hline \multirow[t]{2}{*}{ cashdue } & 0.000016 & & 0.003792 & & 0.003662 & \\
\hline & 0.847 & & 0.297 & & 0.550 & \\
\hline \multirow[t]{2}{*}{ goodwill } & -0.000712 & & -0.110581 & & -0.269437 & \\
\hline & 0.871 & & 0.238 & & $0.033 * *$ & \\
\hline \multirow[t]{2}{*}{ rer14 } & 0.000077 & & 0.004549 & & 0.007036 & \\
\hline & 0.150 & & 0.164 & & 0.179 & \\
\hline \multirow[t]{2}{*}{ remul } & -0.000021 & & 0.007394 & & 0.013112 & \\
\hline & 0.813 & & 0.116 & & $0.022 * *$ & \\
\hline \multirow[t]{2}{*}{ recon } & -000003 & & 0.005640 & & 0.002734 & \\
\hline & 0.967 & & 0.300 & & 0.721 & \\
\hline \multirow[t]{2}{*}{ recom } & 0.000086 & & 0.007505 & & 0.013028 & \\
\hline & 0.178 & & $0.011 * *$ & & $0.001 * * *$ & \\
\hline \multirow[t]{2}{*}{ ci } & 0.000046 & & -0.001343 & & 0.007424 & \\
\hline & 0.638 & & 0.816 & & 0288 & \\
\hline \multirow[t]{2}{*}{ cons } & 0.000022 & & -0.006566 & & -0.019379 & \\
\hline & 0.913 & & 0.553 & & 0.249 & \\
\hline \multirow[t]{2}{*}{ constant $^{2}$} & -5.797860 & & -4.562099 & & -5.610350 & \\
\hline & $0.011 * *$ & & $0.005 * * *$ & & $0.000 * * *$ & \\
\hline Pseudo R ${ }^{2}$ & 0.838 & & 0.516 & & 0.374 & \\
\hline BIC & 417 & & 794 & & 945 & \\
\hline Chi Squared (df) & $129(24)$ & & $266(24)$ & & $399(25)$ & \\
\hline Model Significance $p$ & 0 & & 0 & & 0 & \\
\hline Bank Failures ${ }^{3}$ & 121 & & 117 & & 111 & \\
\hline OBA Banks & 0 & & 0 & & 0 & \\
\hline Observations & 6,728 & & 6,834 & & 7,042 & \\
\hline
\end{tabular}

Table A2: Logistic Regression 2013 Failures Marginal Effects Estimation.

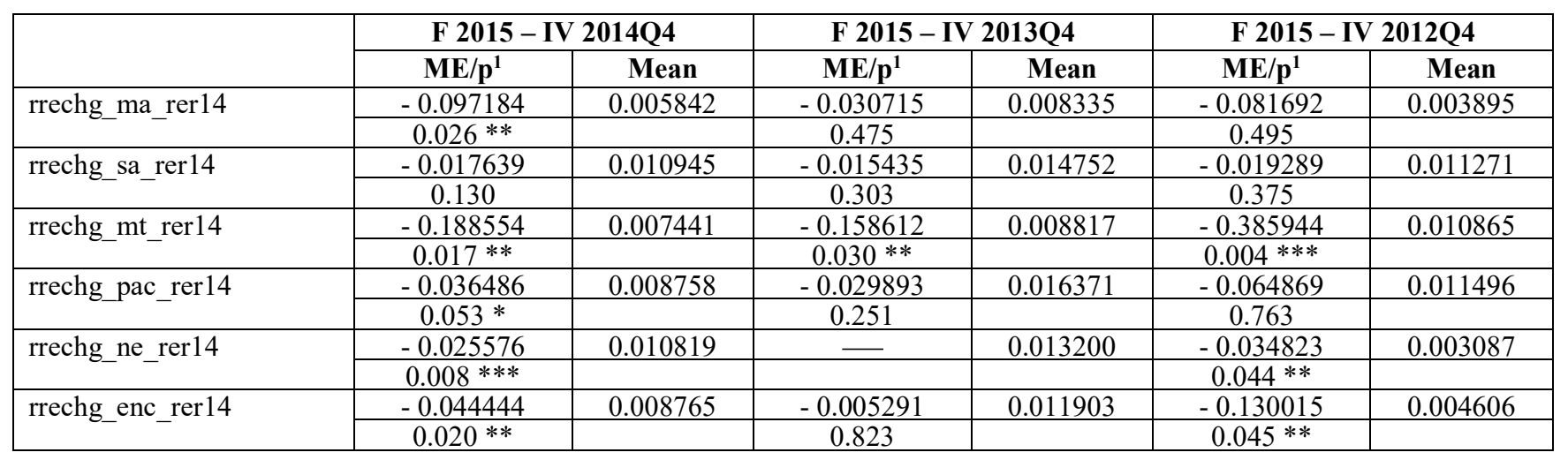




\begin{tabular}{|c|c|c|c|c|c|c|}
\hline \multirow[t]{2}{*}{ rrechg_esc_rer14 } & -0.016491 & 0.007276 & -0.020555 & 0.007295 & -0.087756 & 0.006099 \\
\hline & 0.366 & & 0.543 & & 0.226 & \\
\hline \multirow[t]{2}{*}{ rrechg_wsc_rer14 } & -0.068659 & 0.007923 & -0.088408 & 0.007033 & -0.132364 & 0.006070 \\
\hline & $0.017 * *$ & & 0.216 & & 0.264 & \\
\hline \multirow{2}{*}{ rrechg_wnc_rer14 } & -0.294570 & 0.005498 & -0.140517 & 0.005473 & -0.346151 & 0.005179 \\
\hline & $0.001 * * *$ & & 0.184 & & 0.136 & \\
\hline \multirow[t]{2}{*}{ realgdpchg } & 0.004044 & 0.027859 & 0.009292 & 0.026047 & -0.002742 & 0.004195 \\
\hline & 0.662 & & 0.437 & & 0.697 & \\
\hline asset_ge10B & - & 0.015332 & - & 0.014365 & - & 0.013562 \\
\hline \multirow[t]{2}{*}{ te } & -0.016217 & & -0.019042 & & -0.019860 & \\
\hline & $0.000 * * *$ & & $0.000 * * *$ & & $0.038^{* *}$ & \\
\hline \multirow[t]{2}{*}{$11 \mathrm{r}$} & 0.006371 & & -0.030094 & & -0.012900 & \\
\hline & 0.457 & & 0.145 & & 0.567 & \\
\hline \multirow[t]{2}{*}{ roa } & -0.011349 & & -0.000482 & & 0.002024 & \\
\hline & $0.018^{* *}$ & & $0.062 *$ & & 0.820 & \\
\hline \multirow{2}{*}{ npap_lnlsdebt } & 0.014335 & & 0.011330 & & 0.018832 & \\
\hline & $0.000 * * *$ & & $0.000 * * *$ & & $0.000 * * *$ & \\
\hline \multirow[t]{2}{*}{ sec } & 0.001028 & & -0.001658 & & 0.000778 & \\
\hline & 0.349 & & 0.109 & & 0.692 & \\
\hline \multirow[t]{2}{*}{$\mathrm{bd}$} & 0.000026 & & 0.001323 & & 0.002586 & \\
\hline & 0.975 & & 0.444 & & $0.029 * *$ & \\
\hline \multirow[t]{2}{*}{ cashdue } & 0.001410 & & -0.002092 & & -0.001159 & \\
\hline & 0.315 & & 0.197 & & 0.738 & \\
\hline \multirow[t]{2}{*}{ goodwill } & -0.116330 & & 0.023034 & & 0.023859 & \\
\hline & 0.575 & & $0.018 * *$ & & 0.269 & \\
\hline \multirow[t]{2}{*}{ rer14 } & 0.004277 & & 0.000114 & & 0.000974 & \\
\hline & $0.002 * * *$ & & 0.927 & & 0.626 & \\
\hline \multirow[t]{2}{*}{ remul } & -0.006038 & & -0.005997 & & -0.013243 & \\
\hline & $0.064 *$ & & 0.169 & & $0.054 *$ & \\
\hline \multirow[t]{2}{*}{ recon } & -0.001093 & & -0.001165 & & 0.003135 & \\
\hline & 0.589 & & 0.598 & & 0.427 & \\
\hline \multirow[t]{2}{*}{ recom } & 0.002991 & & 0.000577 & & 0.000707 & \\
\hline & $0.012 * *$ & & 0.587 & & 0.705 & \\
\hline \multirow[t]{2}{*}{$\mathrm{ci}$} & 0.004949 & & -0.001112 & & 0.001097 & \\
\hline & $0.001 * * *$ & & 0.574 & & 0.732 & \\
\hline \multirow[t]{2}{*}{ cons } & 0.003593 & & -0.001451 & & 0.000809 & \\
\hline & $0.019 * *$ & & 0.196 & & 0.709 & \\
\hline \multirow[t]{2}{*}{ constant $^{2}$} & -19.066173 & & -0.690259 & & -4.198170 & \\
\hline & $0.007 * * *$ & & 0.741 & & $0.066 *$ & \\
\hline Pseudo $\mathrm{R}^{2}$ & 0.888 & & 0.562 & & 0.443 & \\
\hline BIC & 277 & & 440 & & 515 & \\
\hline Chi Squared (df) & $70(24)$ & & $226(23)$ & & $288(24)$ & \\
\hline Model Significance $p$ & 0 & & 0 & & 0 & \\
\hline Bank Failures $^{3}$ & 44 & & 44 & & 44 & \\
\hline OBA Banks & 0 & & 0 & & 0 & \\
\hline Observations & 6,261 & & 6,333 & & 6,728 & \\
\hline
\end{tabular}

Table A3: Logistic Regression 2015 Failures Marginal Effects Estimation.

\section{REFERENCES}

[1] Cole, R. A., \& White, L. J. (2012). Déjà vu all over again: The causes of US commercial bank failures this time around. Journal of Financial Services Research, 42(1-2), 5-29.

[2] Sun, J., Wu, D., \& Zhao, X. (2018). Systematic risk factors and bank failures. Journal of Economics and Business, 98, 1-18.

[3] Berger, A. N., \& Bouwman, C. H. (2013). How does capital affect bank performance during financial crises? Journal of financial economics, 109(1), 146-176.

[4] D'Erasmo, P. (2019). Banking Trends: Estimating Today's Commercial Real Estate Risk. Banking Trends, (Q1), 9-15.
[5] Antoniades, A. (2015). Commercial bank failures during the Great Recession: the real (estate) story. European Central Bank.

[6] DeYoung, R., \& Torna, G. (2013). Nontraditional banking activities and bank failures during the financial crisis. Journal of financial intermediation, 22(3), 397-421.

[7] Sanders, A. (2008). The subprime crisis and its role in the financial crisis. Journal of Housing Economics, 17(4), 254-261.

[8] Gorton, G. B. (2008). The panic of 2007 (No. w14358). National Bureau of Economic Research.

[9] Gorton, G., \& Metrick, A. (2012). Securitized banking and the run on repo. Journal of Financial economics, 104(3), 425-451. 
[10] Cole, R. A., \& Gunther, J. W. (1995). Separating the likelihood and timing of bank failure. Journal of Banking \& Finance, 19(6), 1073-1089.

[11] Maddala, G. S. (1983). Limited-Dependent and Qualitative Variables in Economics. New York: Cambridge University Press.

[12] DeLong, E. R., DeLong, D. M., \& Clarke-Pearson, D. L. (1988). Comparing the areas under two or more correlated receiver operating characteristic curves: a nonparametric approach. Biometrics, 837-845.

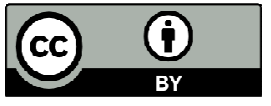

(C) 2021 by the Gerald A. Hanweck Sr, Anthony B. Sanders and Gary S. Fissel. Submitted for possible open access publication under the terms and conditions of the Creative Commons Attribution (CC $\quad$ BY) license (http://creativecommons.org/licenses/by/4.0/). 